\title{
Örgütsel Güven ve Sosyal Adalet Algısının Örgütlerde Sosyal Sermaye Yapısı ile ilişkilerinin İncelenmesi
}

\author{
Seçil BAL TAŞTAN ${ }^{*}$
}

Örgütsel Güven ve Sosyal Adalet Algısının Örgütlerde Sosyal Sermaye Yapısı ile İlişkilerinin İncelenmesi

\section{Özet}

Bu çalışmanın amacı, örgütsel güvenin ve sosyal adalet algısının bireylerin bulundukları kurumdaki sosyal sermaye yapısına yönelik değerlendirmeleri ile ilişkilerinin incelenmesidir. Kavramlar arası ilişkileri belirlemek üzere İstanbul'da bulunan ilk, orta, lise düzeyindeki eğitim kurumları üzerinde bir alan araştırması gerçekleştirilmiştir. Oluşturulan anket formu kesitsel araştırma süreci içerinde belirlenen kurumlarda görev yapmakta olan öğretmen ve okul idarecilerine uygulanmış ve araştırma sonucunda toplam 502 ölçüm aracı değerlendirmeye tabi tutulmuştur. Ö|çeklere Doğrulayıcı Faktör Analizi uygulanmış ve güvenilirlik ve geçerlilik sonuçları incelenmiştir. Elde edilen bulgulara göre, örgütsel güven ( $r=0,549 p<0,01)$ ile sosyal sermaye arasında ve sosyal adalet algısı $(r=0,594 p<0,01)$ ile sosyal sermaye arasında anlamlı, aynı yönde ilişkiler tespit edilmiştir. Yapısal eşitlik analizi ile model testi sonuçları incelendiğinde, elde edilen uyum iyiliği değerlerine göre, modelin kabul edilebilir olduğu görülmüştür(X2/df=3,61; $\quad$ RMSEA=0,063; $\quad$ GFI=0,92; $\quad A G F I=0,82$ $\mathrm{SRMR}=0,044 \mathrm{CFI}=0,88)$.

Anahtar Kelimeler: Sosyal sermaye, Örgütsel güven, Sosyal adalet, Eğitim kurumları.
Examination of the Relations of Organizational Trust and Social Justice with Social Capital Structure in Organizations

Abstract

The aim of the study is to examine the relations of organizational trust and social justice with perceived social capital structure of the organizations. For identifying the relationships among the study variables, a field study has been performed among the primary, medium, high level schools in Istanbul. The questionnaire form was applied among the participants consisting the teachers and the administrators of the schools throughout a cross-sectional study. As a results of the research, totally 502 measurement instruments were taken for the statistical analyses. Confirmatory Factor Analysis was conducted for the scales and reliability and validity results were assessed. The findings revealed that organizational trust $(r=0,549 p<0,01)$ and social justice $(r=0,594 p<0,01)$ had significant and positive relationships with perceived social capital. With Structural Equation Modelling, the model test results were examined and according to the yielded fit index values, the model has been accepted (X2/df=3,61; RMSEA=0,063; GFI=0,92; AGFI $=0,82$ SRMR $=0,044$ CFI $=0,88$ ).

Key Words: Social capital, Organizational trust, Social justice, Education organizations.

\section{Giriş}

Bu çalışmanın temel araştırma sorunsalı, Türk kültüründe "sosyal sermaye" düzeyinin "örgütsel güven algısına" ve "sosyal adalet algısına" bağlı olarak ne ölçüde değişeceğidir. Kuramsal çerçevenin ve araştırma hipotezlerinin oluşmasına temel teşkil eden bu sorunsala yönelik olarak çalışmanın temel amacı, Türk kültüründe, çalışanların sosyal sermaye yapısına ilişkin değerlendirmelerinin örgütsel güven ve sosyal adalet algılarına göre nasıl farklılaştığının ortaya konmasıdır. Özellikle bireylerin sosyal adalete yönelik algılarının ve bireylerin bulundukları örgütte yöneticilere ve örgüte duydukları

\footnotetext{
* Seçil BAL TAŞTAN, Öğr.Gör.Dr., Marmara Üniversitesi, İngilizce İşletme Bölümü, seciltastan@marmara.edu.tr
} 
güven algısının sosyal sermayeye ilişkin değerlendirmeleri ile anlamlı ilişkilerinin olabileceği varsayılmıştır. Böylece, konu ile ilgili çeşitli yerli ve yabancı kaynaklar ve kuramsal ve görgül araştırma sonuçları değerlendirilerek araştırma modeli ve kavramlar arası ilişkiler belirlenmiştir.

Bu çalışmada bağımlı değişken olarak ele alınan ve açıklanmaya çalışılan değişken olarak sosyal sermaye, bireylerin grup üyeliğine dayalı olarak ortaya çıkan ve şekillenen ilişkilerine dayalı bir kavramdır (Bourdieu, 1986). Sosyal bilimler terminolojisine; "fiziki sermaye kavramı" dışında, farklı sermaye tanımlamaları arasına "insani (beşeri) sermaye kavramı" da girmiştir. Fiziki sermayenin dışındaki bu yeni kavram yaygın biçimde 1960'lı yıllarda kullanılsa da, 1930'lu yıllarda endüstri sosyolojisinin bu kavrama işletmeler bazında ilgi duyduğu görülmektedir (Gerşil ve Aracı, 2011, s.41). Şan (2007) ve Cote (2001) tarafından da öne sürüldüğü gibi, sosyal sermaye kavramı öncelikle emeğin örgüt performansına olan katkısının görülmesi ve eğitim gibi bir yatırımla emeğin katkısının olası değerini arttırmasının mümkün olduğunu göstermek açısından dikkat çekicidir. Bu kavramın öneminin ortaya çıkmasında, bilgi toplumu kavramının da önemli rolü bulunmaktadır. Örgütler açısından, çaış̧anların sahip olduğu ve sonradan geliştirdiği tüm becerileri, güven, bilgi paylaşımı, ve kolektif davranışlar mikro ve makro düzeyde sosyal sermaye olgusunun ortaya sağlamaktadır. Cote (2001) aynı zamanda, sosyal sermayenin oluşması için, örgüt içerinde çalışma, işbirliği, uyum, dürüstlük, ortak paylaşım, beşeri ilişkiler, güven ve sosyal dayanışma gibi sosyal erdemlerin var olması gereğinden söz etmiştir. Böylece, sosyal sermaye, söz konusu sosyal erdemlerin çalışanlar arasında paylaşımını öngörmektedir. Bu bakış açısıyla, aralarında güvenin de bulunduğu bu kavramlar, sosyal sermaye olgusunun birer önceli olarak değerlendirilebilmektedir.

Bu bakımdan özellikle insan ilişkileri ve sosyal etkileşimin hem ürünü, hem de niteliğini belirleyen bir özellik taşıyan sosyal sermaye, insani unsurun rol oynadığı mikro düzeydeki örgütler ve kurumlardan, geniş çerçevedeki toplumlara kadar farklı yönleriyle tartışımıştır (Coleman, 1988; Putnam, 2000; Ekinci, 2012). Sosyal sermaye, bir toplumda ki bireylerde bulunan güven unsuru, dürüstlük, bilgi paylaşımı gibi sosyal erdemlerin, bireyleri eşgüdüm halinde çalışmaya, ortak hareket etmeye ve sosyal dayanışmaya teşvik eden bir olgudur (Gerşil ve Aracı, 2011, s.40). Böylece, gerek toplumsal düzeyde, gerekse gruplar ve kurumlar düzeyinde ve insanların işbirliğine ihtiyaç duyduğu bütün toplumsal süreçlerde sosyal sermayenin oluşumundan ve potansiyelinden söz edilebilmektedir. Genel anlamda toplumsal ve örgütsel bağlamda olumlu bir potansiyel olarak literatürde kabul gören sosyal sermayenin çok sayıda sonuçları ve öncelleri tespit edilmesine rağmen yerli ve yabancı literatürde araştırılmaya devam eden dinamik bir kavram olarak karşımıza çıkmaktadır. Bu çalışmada ise, sosyal sermaye kavramının mikro düzeyde ele alınması, örgütsel bağlamda ve bireylerin değerlendirmelerine dayanarak incelenmesi söz konusudur. Bireysel düzeyde ele alındığında, bir örgütün sosyal sermaye yapısına ilişkin değerlendirmelerin ne tür bireysel değişkenlerle ilişkili olabileceği sorununa dayanarak, bireysel düzeyde ölçümlenen güven ve sosyal adalet algıları araştırmamın bağımsız değişkenleri olarak belirlenmiş̧ir. Sosyal sermaye ile ilgili literatürde nispeten daha az araştırımış olan sosyal adalet kavramı, bu çalışmada özellikle toplumsal eşitlik ve sosyal adalet teorileri ile iç içe geçerek kuramsal, felsefi ve sosyal psikoloji bakış açılarıyla değerlendirilmeye çalışıımıştır. 
Öte yandan, bireylerin örgütsel sosyal sermaye potansiyelinin yaratılması doğrultusunda etkili olabilmelerinde örgüte karşı duydukları güvenin önemi daha önceki çalışmalarda vurgulanmıştır (Adler ve Kwon, 2002; Sargut, 2003; Özen ve Aslan, 2006; DeConick, 2010). Bireylerin örgüte güven duymalarında ise örgüt içerisindeki ilişkiler, alınan kararlardaki ve uygulamalardaki hakkaniyet önemli bir belirleyicidir. Bireylerin örgütteki kararların hakkaniyetli olarak alındığına inanmaları ve örgüte ve yöneticilere güven duymaları, örgütteki sosyal yapı içerisindeki rollerini daha etkin yerine getirebilmelerine ve karşılıklı işbirliği ve aidiyetin gelişebilmesine etki ederek, sosyal sermaye potansiyelinin de gelişmesini sağlayabilmektedir (Woolcock ve Narayan, 2009; Fukuyama, 2005; Karagül ve Masca, 2005; Başak ve Öztaş, 2010; Ekinci, 2012).

Bu açıklamalara dayanarak, çalışmanın amacını, örgütsel güvenin ve sosyal adalet algısının sosyal sermaye yapısına ilişkin değerlendirmelerdeki rolünü belirlemek olarak özetlemek mümkündür. Bu amaçla, söz konusu kavramların eğitim kurumları bağlamında değerlendirilmesi önemli bulunmuştur. Eğitim sosyal, siyasal, kültürel, ekonomik, teknolojik ve bilimsel pek çok alanla ilişki içinde olan, yaşam boyunca süren ve sadece tek bir tanımlamayla açıklanamayacak çok yönlü bir olgudur (Buluç, 2007; Toprak ve Bozgeyikli, 2011). Eğitimin amacı, kişileri hem kendi toplumuna hem de yaşadığımı dünyaya uyumlu bir birey haline getirerek, onları çağın gerektirdiği bilgi, beceri ve değerlerle donatmaktır. Bu amaçların gerçekleşmesinde ise, öğretmenlerin ve okul idarecilerinin rolü oldukça büyüktür. Gerek toplumsal düzeyde gerekse gruplar ve kurumlar düzeyinde iyileşme ve gelişmelerin sağlanabilmesi, insan sermayesinin daha etkin hale gelebilmesi ve sosyal sermayenin güçlenmesi açısından öğretmenlerin ve okul yönetiminin algı, tutum ve davranışlarının önemi pek çok çalışmada ifade edilmiştir. Eğitimdeki sosyal sermayenin arttırılması ve var olan potansiyelinin tartışılması açısından Etcheverry'nin (1996, s.22) üniversite öğrencileri üzerinde yapmış olduğu sosyal sermaye araştırması oldukça dikkat çekicidir. Diğer yandan, Coleman (1998) sosyal sermaye potansiyelinin gelişmesindeki en önemli bileşenler olarak toplumdaki eğitim örgütlenmesinden sıkça söz etmiştir. Toprak ve Bozgeyikli (2011, s.126) ise Türkiye'de eğitim kurumlarında yaptıkları araştırma ile öğretmen adaylarının sosyal sermaye düzeylerini inceleyerek, fakülteleri tarafından kendilerine sağlanan destek algısının ve güven temeline dayalı ilişkiler kurmalarının sosyal sermaye birikimine anlamlı etkilerinin olduğunu tespit etmişlerdir. Bununla birlikte, Çelikten, Şanal ve Yeni (2005), öğretmenlik mesleği ve özelliklerini ele aldıkları çalışmalarında, öğretmenlerin sosyal, bilişsel ve duygusal gereksinimlerini ve bireysel sonuçlarını irdelemişler, okullardaki güven ve aidiyet ortamının önemine değinmişlerdir. Tüm bu nedenlerle ve Türkiye'de sosyal sermaye, güven ve sosyal adalet kavramları hakkında eğitimciler üzerinde yapılan çalışmaların hala yeterli olmaması sebebiyle, bu araştırma içine ilk, orta ve lise düzeyindeki okulları kapsayan eğitim kurumlarında gerçekleştirilmiştir. Bu çalışmada bireylerin sosyal sermaye, sosyal adalet ve örgütsel güvene yönelik algıları ve değerlendirmeleri Türkiye bağlamında incelenmiş olup, geliştirilen hipotezler ve elde edilen bulgular Türkiye bağlamına özgüdür.

Bu kapsamda öncelikli ilk bölümde sosyal sermaye, örgütsel güven ve sosyal adalet kavramları ele alındıktan sonra araştırma modeline bağıı olarak geliştirilen hipotezler sunulmuştur. Araştırmanın yöntemi bölümünde ise araştırma ile ilgili yöntem, verilerin analizi ve bulgulara yer verilmiştir. 
Seçil BAL TAŞTAN

Son bölümde araştırmaya ilişkin sonuçlara, kuramsal ve uygulamaya yönelik katkılara ve önerilere değinilmiştir.

\section{Kuramsal ve Kavramsal Çerçeve}

\section{1. Örgütlerde Sosyal Sermaye Kavramı}

Sosyal sermaye kavramının tarihçesi ve felsefi temelleri incelendiğinde, bu alanda Tocqueville'nin "Amerika'da Demokrasi" adlı kitabında Amerikan toplumunun sahip olmuş olduğu zengin "birlik sanatından" söz etmesi ve sosyal sermaye kavramını doğrudan ifade etmese de bugünkü anlamına yakın bir algılayışı vurgulamış olduğu dikkat çekmektedir. Bu kitabında Tocqueville, "halkın çeşitli amaçlarla gönüllü kuruluşlar oluşturarak bir araya gelebilme alışkanlığının yani Amerikalıların sivil ve siyasal amaçlarla kolayca bir araya gelebilmelerinin, Amerikan demokrasisini ayakta tutan unsur olduğunu" ifade etmektedir (Abdioğlu ve Yavuz, 2013, s.30). Bu kitapta öne sürüldüğü gibi, Avrupa'daki daha geleneksel ve hiyerarşik ilişkileri bir arada tutan resmi statü ve yükümlülük bağlarının aksine gönüllü kuruluşlardaki bu "etkileşim", bireysel Amerikalıları birbirine bağlayan "sosyal bir yapıştıııı" görevi görmektedir (Field, 2008:7). Bu açıklamaların ise, 1990'ı yıllarda Coleman (1990) ve Putnam (1995) tarafından öne sürülmüş olan "sosyal sermaye" kavramının içeriği ve tanımlaması ile örtüştüğü gözlenmektedir. Diğer yandan, sosyal sermayeyle ilgili literatür incelendiğinde de bu kavramın kökeninin Durkheim, Marx ve hatta Aristo'nun çalışmalarına kadar dayandığı söylenebilmektedir. Öyle ki, sosyal sermaye kavramı terim olarak ilk defa; öğrencilerinin okul başarısını ortaya koymak, aile ve çevrenin önemini açıklamak amacıyla; Hanifan'ın (1916, s.130) “The Rural School Community Center (Köy Okulu Toplum Merkezi-1916)" çalışmasında kullanılmış ve sosyal sermaye yerel okul katkısı açısından ele alınarak bu tür bir sosyal sermaye zenginliğine ulaşabilmenin yollarına değinilmiştir (Aktaran Abdioğlu ve Yavuz, 2013:30). Max Weber'in de sosyal sermaye kavramına ilişkin düşünceleri bulunmaktadır. Sosyal sermaye Max Weber'in düşüncelerinde varlığını, örtük de olsa, statü gruplarının vazgeçilmez bir öğesi olarak görülen "ortak yaşam biçimine" olan vurguda, karizma ve otorite düşüncesinde ve Protestan Ahlakı tezinde ekonomik ve toplumsal kalkınmada önemli bir unsur olarak ele aldığı manevi motivasyon kurgusunda hissettirmektedir. Weber'in eserlerinde altını çizdiği zihniyet, kültür ve eylemin motivasyonu gibi kavramlar, yeni sosyolojik söylemlerde sosyal sermayenin birer parçası haline gelmektedir. (Field, 2008). Jacobs (1961) toplumun ilerlemesinde sosyal sermayenin önemini dile getirmiş ve sosyal sermaye kavramını, modern metropollerde komşuluk ilişkilerinin kolektif değerine vurgu yapmak amacıyla kullanmıştır (Aktaran Adler ve Kwon, 2002, s.12). Böylece, söz konusu felsefi ve düşünsel köklerin bugünkü post modern örgüt kuramlarında sosyal sermaye kavramın yer alışına zemin hazırlamış olduğu ve kavramının daha iyi anlaşıımasında önemli bir altyapı olabileceği düşünülmektedir. Bu kısa bilgilerin ardından, sosyal sermaye kavramını iktisadi, sosyal ve örgütsel bakış açılarıyla ele alarak betimlemiş olan yazarların açıklamaları ışı̆̆ında, kavramsal değerlendirmeler yapılmaya çalışılacaktır.

Sosyal sermaye (Coleman, 1988; Burt, 2000; Lin 1999; 2001) kavramı beşeri sermaye kavramına ilaveten aktörlerin başarılarını açıklamakta kullanılan ve akademik çalışmalarda sağladığı anlama ve 
ölçme gücü ile geniş yankı yapmış bir sosyal analiz aracı olarak literatürde son yıllarda geniş yer bulmuş ve kuramsal ve kavramsal çerçevelerde incelenmiştir. Bilindiği üzere, beşeri sermaye anlayışının temel tezi, daha donanımlı aktörlerin daha başarılı olduğu yönündedir (Başak ve Öztaş, 2010, s.33). Sosyal sermaye teorisyenleri beşeri sermaye teorisyenlerinden farklı olarak, daha başarılı aktörlerin daha iyi bağlantılı aktörler oldukları tezini savunmaktadırlar (Coleman, 1990; Putnam, 1995; Nahapiet ve Ghoshal, 1998; Özen ve Aslan, 2006; Başak ve Öztaş, 2010). Bu bağlamda, sosyal sermaye; ülkelerin ekonomik faaliyetlerine, toplumsal hayatın etkilerini ortaya koymayı amaçlayan sosyal içerikli bir iktisadi kavramdır. İktisadi bir bakış açısıyla, Bourdieu (1986), sosyal sermayeyi sadece üretenler tarafından fayda sağlanan bir unsur olarak değerlendirmektedir. Diğer yandan, kavramın ilk kullanıılarından Hanifan sosyal sermayeyi, bireyler arası ilişkiler açısından ele almış ve bireylerin gündelik hayatlarındaki somut kavramlardan ayrı tutarak, iyi niyet, arkadaşlık ve sosyal birlikteliği meydana getiren, bireyler ve aileler arasındaki ilişkiler olarak tanımlamıştır (Aktaran Keskin, 2008, s.10). Sosyal sermaye; en az iki kişi arasında, güvene dayalı bir şekilde kurulabilen iletişim imkanı ve daha geniş bir tanımlamayla, toplumu oluşturan fertler, sivil toplum örgütleri ve kamu kurumları arasındaki koordinasyon faaliyetlerini kolaylaştırarak toplumun üretkenliğini arttıran, güven, norm ve iletişim ağı özellikleri (Temple, 2000, s.23) olarak tanımlanmaktadır. Coleman'a (1988) göre ise sosyal sermaye istenilen hedeflere ulaşılmasını kolaylaştıran, duruma göre beşeri sermaye ile bütünleyici bir yapı arz eden bir kavramdır. Diğer yandan, Coleman (1988) tarafından ortaya atılan ve Burt (2000) ve Lin (2001) tarafından destek gören dayanışmacı ve aracı sosyal sermaye kavramları anlamlı, sık tekrar eden ve uzun süreli ilişkilere olanak tanıyarak, örgütlerde dayanışma ve işbirliğini arttırmaktadır. Bu ilişkiler sonucu ortaya çıkan normlar, denetim mekanizması ve güven sayesinde toplulukçu (kollektif) hareketin maliyeti azalabilmekte, gruplaşma ve tehditlerle mücadele kolaylaşmakta, maddi ve manevi destek bulunabilmektedir (Burt, 2000; Başak ve Öztaş, 2010). Coleman (1988) tarafından ifade edildiği gibi, dayanışmacı sosyal sermayenin güçlü olduğu örgütlerde, yoğunluğu yüksek ağbağların hem tek tek o ağbağın parçası olan aktörler hem de bir bütün olarak ağbağ/grup için önemli faydalar sağlanabilmektedir. Öztaş (2007) tarafından da öne sürüldüğü üzere, bu tür ağbağ yapılarında bireyler birbirleriyle sıkça temasta bulunmakta ve sık temaslar ortak davranış normlarını ve bireylerin birbirlerine karşı beklentilerinin oluşmasını sağlamaktadır (s.82). Putnam’a (1995) göre sosyal sermaye, "ortak hedefleri sağlamak amacıyla aktörlerin işbirliği halinde ve etkin şekilde ortak hareket etmesini sağlayan güven, sosyal normlar ve ağlar gibi sosyal örgütlenmenin özelliklerinden oluşan yapılardır" (Aktaran Altan, 2007:224). Sosyal sermaye, topluluklar ya da ulusların sahip olabileceği fakat bireylerin sahip olamayacağı bir kavramdır. DeFlippis (2000, s.786) Putnam'ın teorisinde belirttiği toplumsal aktörler arası ilişki ve ağlar konusuna vurgu yaparak, sosyal sermayenin kişisel hedeflere ulaşmaktan öte, birlikte hareket ya da kolektif eylem olarak öne çıkmakta olduğu belirtmektedir. Birlikte hareketin esaslarından olan işbirliğinin tesis edilebilmesi ise karşıııkılık ve bir araya gelerek etkileşimde bulunmaya bağlı olmaktadır (Tüysüz, 2011, s.14).

Görüldüğü gibi, sosyal sermaye, bireyler ve toplum arasında işbirliğini ve dayanışmayı artıran, çok önemli, informal bir değerdir. Ekonomik alanda, işlem maliyetlerini düşürürken, siyasi alanda hükümetlerin ve modern demokrasinin başarısı için gerekli olan birlikte yaşamın çeşitliliğini ve kalitesini yükseltmektedir (Fukuyama, 2000). Putnam'a göre sosyal sermayenin özelliklerinden sosyal 
bağlar, normlar ve güvenin, insanların ortak hedef belirlemesinde ve ortak faaliyetlere katılımında etkili olmaktadır (Onyx ve Bullen 2000). Bu bağlamda sosyal sermaye güven, karşılıkııık, ağlar, birlikler, birlik ve grup üyeliği, sosyal normlar ve ortak faaliyetler şeklinde tanımlandığı görülmektedir (Tüylüoğlu, 2006; Karagül ve Masca, 2005; Şimşek, 2013). Dale (2005) de sosyal sermayeyi oluşturan bileşenleri sözleşme, güven, ortaklaşa hareket, ortak normlar, bilginin yayılması ve paylaşılan gelecek anlayışı olduğunu belirtmektedir (İçinde aktaran Öğüt ve Erbil, 2009).

Söz konusu kuramsal açıklamalara dayanarak, sosyal sermaye, kişi ve kurumlar arası güvene dayalı ilişkilerin, ekonomik etkinliğe ve üretime yansıması şeklinde kabul edilmektedir (Karagül ve Masca, 2005, s.39). Bununla birlikte, sosyal sermaye, güven, karşlıklılık, norm, kültür ve topluluk temelleri oluşturan sosyal ilişkilerin bir sonucu olarak özetlenmektedir (Condeluci, Ledbetter, Ortman, Fromknecht, DeFries, 2008). Kavramsal olarak bakıldığında, sosyal sermayenin, bir topluluğun, bir toplumun veya bir ülkenin sahip olabileceği ve o alanın sınırları dâhilinde kurulan/kurulacak ilişkilerden doğan bir kaynak olarak değerlendirildiği görülmektedir (Bourdieu, 1986; Coleman, 1990; Putnam, 1995). Sosyal sermayeye ilişkin yapılan son açıklamalar, sosyal sermayeyi, genel olarak vatandaş katıımı veya sağlık, başarı, mutluluk vb. belirli topluluk göstergeleriyle bağdaştırmaktadır (Özmen, Aküzüm, Koçoğlu, Tan ve Demirkol, 2014). Sosyal sermaye çerçevesi içinde en az yer alan kişilerin, sosyal sermaye aracılığı ile oluşacak yardım, sempati, dostluk ve sağılık konularında en çok yarar elde edecek kişiler olduğuna dikkat çekilmektedir. Bu durumun, sosyal sermayeden yararlanmanın önemini de ortaya koymakta olduğu görülmektedir.

Öte yandan, sosyal sermaye uygulandığı düzey açısından ele alındığında, makro ve mikro olmak üzere iki düzeyden oluşmaktadır (Akçay, 2005, s.205). Makro düzey sosyal sermaye, örgütlerin faaliyet gösterdiği kurumsal yapıyı kapsamaktadır. Hukukun üstünlüğü, yerelleşme, yönetim biçimi, demokrasinin yerleşmesi, yasal çerçeve ve politika oluşturma süreçlerine katılım makro düzeyin bileşenleridir. Ülkeler arası yapılan çalışmalarda sosyal sermayenin bu düzeyi kullanılmaktadır (Akçay, 2005, s.205). Mikro düzey sosyal sermaye ise, bireyler ve gruplar arası ilişkiye dayanmakta, bilişsel ve yapısal olmak üzere ikiye ayrılmaktadır. Bilinçsel sosyal sermaye güven, karşılıklılık ve dayanışma gibi değerler ile davranış ve tutumlar gibi normları kapsarken; yapısal sosyal sermaye yatay örgütleri, ilişki ağlarını ve yerel düzeydeki kurumların etkinliklerini içermektedir (Akçay, 2005, s.205; Tüysüz, 2011, s.19). Bununla birlikte, sosyal sermaye kavramı yönetsel/örgütsel çerçevede türleri açısından incelendiğinde, içsel ve dışsal sosyal sermaye olarak değerlendirilebilmektedir (Coleman, 1990; Özen ve Aslan, 2006; Pastoriza, 2008; Paşamehmetoğlu, 2010). Bu çalışmada da açıklanmak istenen ve çalışmanın bağımlı değişkeni olarak ele alınmış olan temel kavram “içsel yönden değerlendirilen sosyal sermaye yapısı"dır. Bunun da temelinde Putnam (1995), Coleman (1990), Fukuyama (1995) ve Adler ve Kwon'un (2002), sosyal sermaye kavramı üzerine yaptığı çalışmalarda, "içsel" (ya da bağlayıcı, sosyal-merkezli) ve "dışsal" (ya da birleştirici, ben-merkezli) sosyal sermaye türlerini ele alarak iki gruba ayrılabileceğini belirtmiş olmalarıdır. Literatürde yer alan sonraki çalışmalarda da sosyal sermaye yapısı içsel ve dışsal olarak iki grupta incelenmiş ve öncülleri ile sonuçları bağlamında da farkIılaşmakta oldukları ifade edilmiştir (Pastoriza, 2008; Özdemir, 2008). Türkiye'de de içsel ve dışsal sosyal sermaye yaklaşımları arasındaki farklııkların Özen ve Aslan (2006:133) tarafından incelenmiş 
olduğu görülmektedir. Özen ve Aslan (2006) tarafından yapılan çalışmada, Türkiye'de ekonomik işlemlerin yürütülmesinde birincil ilişkilere dayalı verili güven ile ikincil ilişkilere dayalı ilişkisel güvenin ne ölçüde yaygın olduğu anlaşılmaya çalışılmıştır. Türk toplumunun sosyal sermaye potansiyelinin ne düzeyde olduğunu belirlemek amacıyla Ankara'da bulunan Ortadoğu Sanayi ve Ticaret Merkezinde faaliyet gösteren bir grup örgüt üzerinde nitel yöntemle yapılan araştırma aracılığıyla, örgütler arası ilişkileri incelemişler ve çıkarımda bulunmuşlardır. Çalışmalarında sosyal sermaye potansiyelinin içsel ve dışsal sosyal sermaye yaklaşımlarına göre farklılaşabileceği ileri sürülmüştür. Türk toplumunun sosyal sermaye potansiyeli, içsel sosyal sermaye yaklaşımına göre düşük, dışsal sosyal sermaye yaklaşımına göre yüksek olarak değerlendirilmiştir. Analiz sonuçlarında çıkan bulgular, dışsal sosyal sermaye yaklaşımını destekler biçimde, işletme sahiplerinin, karşııklı ekonomik çıkar temeline dayalı olarak zaman içinde oluşan arkadaşlık bağlan yoluyla güven tesis edebildiğini ve sosyal sermaye yaratabildiğim göstermiştir (Özen ve Aslan, 2006). Bu tür bir inceleme Türkiye'de Paşamehmetoğlu (2010) tarafından da yapılmış olup, sosyal sermayenin iki grupta belirginleştiği sanayi işletmeleri üzerinde yapılmış olan çalışması sonucunda desteklenmiştir. Böylece, tüm bu çalışmalar, bu araştırma çalışmasında, sosyal sermaye kavramının iki boyutunu göz önünde bulundurarak, çalışmanın ana amacı doğrultusunda sosyal sermaye kavramına odaklanılmasında esin kaynağı olmuştur.

Sosyal sermaye konusu, örgütler ve yönetim olgusu açısından önemli bir değişken olarak yabancı ve Türk yazarlarca ve farklı disiplinler içerisinde kavramsal ve görgül olarak incelenmiştir (örn., Fukuyama, 1995; Nahapiet ve Ghoshal, 1998; Karagül ve Masca, 2005; Özdemir, 2008; Pastoriza, 2008; Ayios, Jeurissen ve Spence, 2010; Başak ve Öztaş, 2010; Ekinci ve Karakuş, 2011). Literatürde yer alan çalışmalarda, örgütsel sosyal sermayenin örgüt performansı, örgüt başarısı, yenilik, verimlilik ve çalışanlar üzerindeki olumlu etkisini ortaya koymaktadır (örn., Nahapiet ve Ghoshal, 1998; Schuller, 2001; Cohen ve Prusak, 2001; Pastoriza, 2008, Özdemir, 2008; Hau, Kim, Lee ve Kim, 2013). Nahapiet ve Ghoshal (1998) sosyal sermaye kavramının yapısal ve ilişkisel boyutun yanında bilişsel boyutta da incelenerek tanımlanabileceğini belirterek, sosyal sermayeyi yapısal, ilişkisel ve bilişsel olmak üzere 3 boyut ve 9 alt boyut ile tanımlamışlardır. Nahapiet ve Ghoshal (1998) tarafından yapılan tanımlamaya göre, yapısal boyut; birimler ve insanlar arasındaki sosyal etkileşimi ele almakta, ağların kendisi bu boyutun temelini oluşturmaktadır. Yapısal sosyal sermaye bazı yazarlarca sosyal etkileşim bağı olarak da ifade edilmiştir (Chang ve Chuang, 2011; Chiu, Hsu ve Wang, 2006; Tsai ve Ghoshal, 1998). Sosyal etkileşim bağı da, "bir aktörle diğer aktör arasında bilgi ve kaynak akışını sağlayan kanallar" olarak tanımlanmaktadır (Tsai ve Ghoshal, 1998). Yapısal sosyal sermaye boyutu altında, aktörler arasındaki ilişkilerin yapısal durumuna yer verilmiş olsa da, örgüt yapısı ile ilgili kavramlar da sosyal ilişkileri etkileyerek yapısal sosyal sermayede ya da diğer ismiyle sosyal etkileşim bağlarında etkili olabilmektedir (Mcpodolny ve Baron, 1997, s. 673). Sosyal sermayenin ilişkisel boyutu; güven, güvenilirlilik, normlar, yükümlülükler, özdeşleşme gibi ilişkilerin kaynaklarını ifade etmektedir. Bilişsel boyut; ortak dil, kodlar, hikayeler gibi ilişkilerin önemli öğelerinden oluşmaktadır. Iliş̧kisel boyut, "bireylerin etkileşim yoluyla birbirleri arasında geliştirmiş oldukları ilişkilerin özellikleri" (Nahapiet ve Ghoshal, 1998, s. 254) şeklinde tanımlanmakta ve ilişkisel sosyal sermaye güven, karşılıklılık normları ve kimlik alt boyutlarıyla açıklanmaktadır (Chang ve Chuang, 2011; Chiu vd., 2006; Nahapiet ve Ghoshal, 1998). Nahapiet ve Ghoshal (1998, s. 253), bilişsel sosyal sermayeyi ise; "bir 
ağdaki bireylerin o ağa ait konularda ortak anlayış ve paylaşımlar geliştirmesi" olarak tanımlamışlar ve bu paylaşımların sosyal sermayeyi güçlendirdiğini belirtmişlerdir. Bu bakış açısıyla, bilişsel sosyal sermaye birçok araştırmacı tarafından paylaşılan dil ve paylaşılan vizyon alt boyutlarıyla tanımlanmiştır (Chang ve Chuang, 2011; Chiu vd., 2006; Nahapiet ve Ghoshal, 1998; Wasko ve Faraj, 2005). Bu boyutlar, aynı zamanda sosyal sermayenin kaynaklarını da ifade etmektedir. Bu çalışmada ise, sosyal sermayenin, yapısal boyutu; ağ bağları, ağ konfigürasyonu ve uyarlanabilir örgüt alt boyutları ile, ilişkisel boyutu; güven, normlar, yaptırımlar ve kimlik alt boyutları ile; bilişsel boyutu ise; paylaşılan dil ve paylaşılan hikayeler alt boyutları ile tanımlanmıştır. Böylece, bu çalışmada Nahapiet ve Ghoshal (1998) tarafından öne sürüldüğü gibi sosyal sermaye kavramı yapısal, ilişkisel ve bilişsel boyutları ile incelenmiştir.

\section{2. Örgütsel Güven ve Sosyal Sermaye ilişkisi}

Sosyal sermaye konusunda yapılan değerlendirmeler genel olarak; sosyal normlar, iletişim, güven, bireysel özellikler ve kültürel farklılaşmalar, değerler, sosyal bütünleşme, grup aidiyeti ve adalet yapısında ilişkin algılar ekseni etrafında yoğunlaşmaktadır. Sosyal sermaye yaklaşımının öncülerinin yaptığı sosyal sermaye tanımlarına bakıldığında, göze çarpan anahtar sözcükler ise, "sosyal yapı", "işbirliği" ve "ortak fayda" kavramlarıdır. Putnam (1995, s.67) sosyal sermayeyi, "ortak fayda için eşgüdümü ve işbirliğini kolaylaştıran, sosyal güven, normlar ve ağlar gibi sosyal örgütlenme özellikleri" olarak tanımlamaktadır. Putnam (1995) ve Adler ve Kwon'a (2002) göre, sosyal sermayenin kaynağı topluluktaki sosyal ilişkileri biçimleyen egemen değerler, inançlar, ve normlardır. Bu noktada, "güven" kavramı, sosyal sermayenin oluşumunu etkileyen önemli bir kavram olarak kabul edilmekte olup, güven kavramının statüsü sosyal sermayeyi doğrudan belirleyici bir etki yaratabilmektedir.

Güven konusunda yaptığımı literatür okumaları neticesinde, bu kavramın, içinde sosyoloji, iktisat, siyaset bilimi, örgütsel davranış ve yönetim ve organizasyon biliminin de olduğu çok geniş bir alanda sıkça üzerinde durulduğu ve tartışıldığı gözlenmektedir. Özellikle, Krackhardt (1992), Behn (1995) ve Adler ve Kwon (2002) gibi yazarların yönetim biliminde güven konusunu inceledikleri, Putnam (2000) ve Fukuyama'nın (2005) ise güven kavramını siyaset bilimi konuları içerisinde ele alarak, bu kavramın sosyal siyaset ve yönetim bilimi açısından da tartışılmasına zemin hazırladıkları görülmektedir. Öte yandan, Giddens (2004), Granovetter (1985) ve Luhmann (1998) güven üzerine yaptıkları çalışmalarla sosyoloji bilimi açısından değerlendirmeler yapmışlardır. Giddens'e (2004, s.39) göre, güven, belirli sonuçlar ya da olaylar bütünü göz önüne alındığında bir kişi ya da bir sistemin güvenirliğine olan itimat olarak tanımlanmaktadır. Güven, diğer insanların davranış ve düşünceleri hakkında istenilen beklentilerdir. Bu durumda güven, kişisel risk alabilme, işbirliği, düşük sosyal çatışma ve sosyal sermaye ve düzen ile gerçekleşmektedir (Ören, 2007). Başak ve Öztaş (2010, s.35) tarafından da ifade edildiği gibi başkasının dürüstlüğüne, seviyesine ya da soyut ilkelerin (teknik bilgininin) doğruluğuna karşı beslenen inanç söz konusu itimat veya güveni açıklamaktadır. Korczynski (2003, s.65) ise, güveni; mübadele aktörleri/partnerleri arasındaki ilişkinin bir özelliği olarak görmüş, güvenirliği ise mübadele aktörünün bir özelliği olarak belirtmiştir. Güven genel olarak, bir kişinin, diğer bir kişinin fırsat bulduğunda zayıf yanını kendi çıkarı doğrultusunda istismar etmeyeceğine dair 
inancı olarak tanımlanmaktadır (Korczynski, 2000, s.4). Böylece, güven, bir ilişkinin tarafı olan bir kimsenin var olan ya da ortaya çıkabilecek bir zayıflığının, ilişkinin diğer tarafındaki kişi tarafından istismar edilmeyeceğinden emin olmasıdır (Başak ve Öztaş, 2010, s.35). Sosyal sermaye ve güven kavramları üzerinde önemli incelemeler yapmış olan Fukuyama (1995) sosyal sermayeyi güven duygusunun üzerine inşa edilmiş bir kavram olarak ele almaktadır. Fukayama (1995) sosyal sermayenin toplumun tamamında veya bir bölümünde güven duygusunun hakim olmasıyla kazanılan bir yeti olduğuna işaret etmektedir. Ayrıca güven; ortak normlara dayalı, düzenli, dürüst ve işbirliğine yönelik davranışların gerçekleştiği bir grup ya da toplum içinde oluşan beklentileri nitelemektedir (Gerşil ve Aracı, 2011, s.44). Woolcock ve Narayan $(2000$, s.6) tarafından da ifade edildiği gibi, bireyler ve çıkar grupları arasındaki bağlılık ve güven, sosyal sermaye kavramının tanımlandığı birçok açıklamada rol oynayan önemli unsurlardır.

Tüm bu özelliklerinin yanı sıra, çevresel ve ekonomik değişimlerin oranının artması, esnekliğe ve işbirliğine duyulan ihtiyacın yükselmesi, takım ve takım çalışmalarına inancın yükselmesi, çalışanlarla ilişkilerin ve kariyer kalıplarının değişmesi örgütsel güvenin önemini artırmıştır. Güven olmaksızın hiçbir kurumun hedefini gerçekleştiremeyeceği değerlendirilmektedir. Aynı zamanda güven etkili ilişkilerin önemli öğelerinden birisidir ve karşılıklı güven duyulması yaşamsal bir durum olarak karşımıza çıkmaktadır. Çağdaş örgüt ve yönetim kuramlarının etkisiyle birçok araştırmacı ve uygulayıcı zaman içerisinde örgütteki insan öğesine daha fazla önem vermeye başlamışlar; bunun sonucu olarak bireyler arası ilişkilerin en önemli unsurlarından birisi olan güven, örgütsel yaşamda çok önemli bir yer edinmiş ve buna paralel olarak örgütsel güvene ilişkin çalışmalara örgüt, yönetim ve örgütsel davranış alanlarındaki ilgi giderek artmıştır (Yücel ve Kalaycı, 2009, s.116; Polat, 2009, s.2; Eğriboyun, 2013, s.10).

Örgütsel güven; aynı zamanda örgütün, çalışanların katkısına değer vermesi ve mutluluğunu önemsemesine yönelik algılar ve çalışanları etkileyen kural, politika ve eylemleri örgütün gönüllü olarak gerçekleştirdiğine dayalı duygulardır (Eisenberger vd, 1986, s.504). Gilbert ve Li-Pang (1998), içinde aktaran Ribbers, 2009, s.7) örgütsel güveni “bir güven hissi ve çalışana destek, çalışanın dürüst ve bağlılık konusunda başarıı olacağına dair inanç" olarak tanımlamıştır. Mishra, Jitendra, Morrisey ve Molly (1990, içinde aktaran Durdağ ve Naktiyok, 2011, s.15) de "çalışanların örgütün sağladığı desteğe ilişkin algısı, liderin doğru sözlü olacağına ve sözünün ardında duracağına yönelik inancıdır" şeklinde açıklamışlardır. Asunakutlu (2006, s.19)'nun ifadesine göre de örgütlerde hem yöneticiler, hem de çalışanlar açısından genel anlamda bütün ilişkilerin temeli olarak kabul edilmekte ve bir tarafın diğer tarafın eylemlerinden zarar görmeyeceğinden veya karşı tarafın risk yaratmayacağından emin olması şeklinde açıklanmaktadır. Örgütsel güven, Nyhan ve Marlowe (1997, s.618)'un araştırmalarında ise genel olarak örgüte güven ve yöneticiye güven kavramlarından oluşmakta ve bu iki kavramın bileşimi alan yazında örgütsel güven olarak adlandııımaktadır. Bu bağlamda güven hem yatay hem de dikey anlamda tüm örgüt içi ilişkilerin temelini oluşturmaktadır (Demircan ve Ceylan, 2003, s.142). Güvenin, bireylerarası ilişkilerden yola çıkarak örgütsel yaşamdaki etkilerini inceleyen araştırmalarda ise çalışanlar arası güven, yöneticiye duyulan güven ve bir kurum olarak örgüte duyulan güven olmak üzere üç ana başlık öne çıkmaktadır (Aksoy, 2009, s.77; Durdağ ve Naktiyok, 
2011, s.14). Büte (2011,s.175) de yaptığı araştırmasında örgütsel güven konusunu yöneticiye güven, işletmeye güven ve çalışma arkadaşlarına güven olmak üzere üç başlık altında açıklamaktadır. Topaloğlu (2010, s.44) ise örgütsel güveni sınıflandırırken konuyu örgütsel güvenin bileşenleri olarak değerlendirmiş ve yöneticiye güven, çalışma arkadaşlarına güven ve prosedürlere güven üzerinde durmuştur. Shockley-Zalabak, Ellis ve Winograd (2000) ise örgüte güveni bireylerin örgütsel ilişkiler ve davranışlar ağından beklentileri olarak değerlendirmektedir. Örgüte güven tanımı Tan ve Tan (2000) tarafından da bir örgütün çalışanlar tarafından algılanan dürüstlüğünün global değerlendirilmesi olarak ifade edilmiştir.

Bu bağlamda, sosyal sermayenin oluşumu için önemli bir unsur olan örgütsel güven, örgüt içinde ilişkileri bir arada tutan temel "sosyal yapıştırıcı" olarak görülmektedir (Pussa ve Tolvanen, 2006, s.30). Güven duygusunun varlığının çalışanların iş davranışlarını ve işe yönelik tutumlarını etkilediği çeşitli araştırmalarla saptanmıştır (Özmen vd., 2014, s.335). Karar organı konumundaki kişiye güven duyma bireyde karar vermeye bizzat katılıyormuşçasına bir tatmine neden olmakta ve karşılıklı güvenin de pekişmesine yol açabilmektedir (İşcan ve Sayın, 2011, s.203). Örgütsel güven ve sosyal sermaye yapısı arasındaki ilişki literatürdeki çalışmalarda sıkıkla tartışılmış, özellikle içsel sosyal sermaye kavramını inceleyen yazarlar tarafından sosyal sermayenin güçlü bir belirleyicisi olabileceği vurgulanmıştır (Putnam, 1993; Fukuyama, 2005; Adler ve Kwon, 2002; Özen ve Aslan, 2006). Literatürden elde edilen bilgilere göre, sosyal sermaye ve güven kavramı arasındaki ilişki ilk olarak Coleman, Putnam ve Fukuyama tarafından açıklanmıştır. Coleman (1988: 98)'a göre; kapalıık özelliği gösteren ağbağlardaki yapılar, düzenli temaslar ve davranış normları aracılığıyla güven ve itibarın inşa edilmesini, dolayısıyla da sosyal sermayenin ortaya çıkmasını sağlamaktadır. Coleman (1988) sosyal sermayenin bir kaynağı temsil ettiğini ve karşılıklılık (reciprocity) beklentilerini içermekte olduğunu ifade etmektedir. Ilişkilerin yüksek derecede güvenle ve ortak değerlerle yönetilmesiyle bireyin ötesine geçmekte ve bu sebeple sosyal sermaye, üretkenliği kolaylaştırıcı bir fonksiyona sahip olmaktadır (Field, 2008, s.28; Tüysüz, 2011, s.12). Benzer şekilde Francois (2003), güvenilirliğin bir toplumun kültürünün ekonomik olarak uygun bir parçası olduğunu, böylece onun sosyal sermayesini içerdiğini ifade etmektedir. Böylece, içinde güvenin yaygın olduğu bir topluluk, buna sahip olmayan benzer bir topluluktan çok daha fazla şey başaracak kapasiteye sahip olabilmektedir (Tüysüz, 2011, s.12). Bu anlamda güven, toplumun bütününü ilgilendiren yararlı sonuçlar için, bireyleri gönüllü olarak işbirliğine iten ve bu yolla iyi toplumun oluşturulmasını kolaylaştıran temel değerdir (Erdem ve Özen, 2003). Fukuyama (2005, ss.25-27) ise, sosyal sermayenin toplumda yaygınlık kazanan güven aracılı̆̆ıla ortaya çıkan bir yeterlilik olduğunu öne sürerek, toplumu oluşturan tüm temel parçalar (aile ve ulus gibi) arasında içselleştirildiğini belirtmektedir. Böylece, Fukuyama'ya (2005) göre, güçlü bir toplumsal sosyal sermayeye sahip olabilmek, o toplumdaki yüksek güvene bağlı olmaktadır. Uslaner'e (1999) göre sosyal sermaye, "bir değerler sistemini, özellikle de sosyal güveni" yansıtmaktadır. Adler ve Kwon (2002, ss.21-25) ise, sosyal sermaye kavramını önemli ölçüde bir "sermaye", yani bir "kaynak" olarak görmüşler; güveni ise, "fırsat" ve "beceriye" ek olarak bu sermayenin oluşması için gerekli "motivasyonu" sağlayan etmenlerden birisi olarak tanımlamışlardır. Lee ve Croninger (2001, s.165) tarafından eğitim kurumlarında yapılan bir araştırmada, sosyal sermayenin 
en temel belirleyicisi olarak güven unsuru tespit edilmiştir. Narayan ve Cassidy (2001, s.60) ise, sosyal sermayeyi çok boyutlu bir yaklaşımla ele alarak ölçümlenmesi ve geçerliliğinin analiz edilmesi amacıyla yaptıkları çalışmada, güvenin sosyal sermaye endeksini oluşturan önemli ve anlamlı bir boyut olarak saptandığını belirtmişlerdir. Türkiye'de gerçekleştirilen karşılaştırmalı çalışmaların ve analizlerin ortaya koyduğu ortak bir bulgu da Türkiye'nin sosyal sermayesinin düşük olduğudur (örn. Özen ve Aslan, 2006; Aydemir ve Tecim, 2012). Her ne kadar sosyal sermaye konusunda üzerinde uzlaşma sağlanmış bir ölçüm aracı olmasa da bazı değişkenler bu ölçüme ışık tutacak veriler sunmaktadır. Bu değişkenler arasında güven, sivil ve siyasal katılım, dayanışma ve işbirliği, topluluk duygusu, değerler vb. gibi değişkenler sayılmaktadır. Özellikle kişilerarası güven oranları ve sivil toplumsal faaliyetlerin çeşitliliği ve katıım oranları itibariyle ifade edildiğinde ülkemizde sosyal sermaye göstergelerinin oldukça düşük olduğu bulgulanmıştır (örn. Kalaycıoğlu, 2007; Aydemir, 2011; Aydemir ve Özşahin, 2011; Tecim, 2011; Tüysüz, 2011). Türkiye için sosyal sermaye göstergeleri incelendiğinde oranların dünya geneline göre daha düşük seviyelerde olduğu görülmektedir. Öyle ki, bir gösterge olarak genel güven indeksinde Türkiye dünya ülkeleri içerisinde son sıralarda yer almaktadır ${ }^{1}$ (Aydemir ve Tecim, 2012, s.51).

Diğer yandan, sosyal sermaye yapısının bir belirleyici olarak güven kavramı Türkiye'de yapılan kuramsal ve kavramsal çalışmaların bulguları ile incelendiğinde, elde edilen görgül bulguların da söz konusu sosyal sermaye ve güven ilişkisini destekleyen nitelikte olduğu gözlenmektedir. Özen ve Aslan (2006) içsel ve dışsal sosyal sermaye yaklaşımları açısından Türk toplumunun sosyal sermaye potansiyelini incelemiş oldukları çalışmada, sosyal sermaye ve güven arasındaki ilişkiye vurgu yapmışlardır. Türkiye'de yaygın güven tipinin, Korczynski'nin (2000, s.5) tanımladığı "diğer tarafın içsel normlarının bilgisine dayalı", toplumsal düzenin özünde var olduğu düşünülen kurumsal temelli güven olduğu kabul edilmektedir (Özen ve Aslan, 2006, s.139). Sargut (2001, s.112) ise, Türk toplumunda yaygın güven tipinin, kişisel çıkar aracılığıyla özendirilen, evrensel kurallar ve işlem standartlarıyla geliştirilen bilişsel bir güven olmaktan çok, diğerleriyle olan duygusal bağlara dayalı duygusal güven olduğunu belirtmektedir. Töremen (2002, s.560) Türkiye'deki eğitim kurumlarında sosyal sermayenin kavramsal olarak çözümlenmesine ilişkin yapmış olduğu çalışmasında, güven, aidiyet duygusu ve sadakatin, sosyal sermayenin oluşumunu ve güçlenmesini belirleyen en önemli unsurlar olduğunu öne sürmektedir. Oba ve Semerciöz $(2005$, s.165) yapmış oldukları bir araştırma sonucunda, örgütler arasında oluşan güvenin aile, akrabalık, hemşerilik gibi duygusal bağlardan ziyade, itibar, teknik kapasite, coğrafi yakınlıktan ötürü karşı tarafın bilgisine kolay ulaşma ve sanayi bölgesi derneğinin gözetimi ile oluşan "rasyonel" temele dayalı ilişkisel bir güven olduğunu ortaya koymuşlardır. Toprak ve Bozgeyikli (2011) ise öğretmen adaylarının sosyal sermaye düzeylerini çeşitli demografik özelliklere göre inceledikleri çalışmada sosyal sermayenin önemli bir belirleyici olarak güven kavramını vurgulamışlardır. Ören (2001), örgütlerde birbirlerine güvenen insanların, güvenmeyenlere kıyasla daha zengin, esnek ve buluş̧̧u bir ortamda çalıştıklarından söz ederek buna bağlı olarak örgü-

\footnotetext{
${ }^{1}$ Dünya Değerler Araştırması (DDA) Raporu'ndan (2007) elde edilen sonuçları kapsamaktadır.
} 
tün ekonomik ve sosyal değerinin gelişebildiğini ifade etmiştir. Abdioğlu ve Yavuz (2013, s.42) tarafından Türkiye'deki özel mülkiyetli endüstri işletmelerinde sosyal sermayenin ölçümlenmesi ve raporlanmasına yönelik yürütülmüş olan çalışmada, normlar, güven ve sosyal ağlar, sosyal sermayenin belirleyicileri olarak tespit edilmiştir. Özellikle güven unsurunun, sahip olduğu ortalama değer ve sosyal sermaye yapısının toplam varyansını açıklaması bakımından, önemli ölçüde role sahip olduğu gözlenmiştir (Abdioğlu ve Yavuz, 2013, s.42). Bununla birlikte, Topçuoğlu (2003) ve Özdemir (2006) aile temelli sosyal sermayenin aile şirketleri olarak nasıl vücut bulduğunu belirterek yakın çevre ve aile ile güven ilişkilerinin sosyal sermaye yaratmadaki etkilerinden söz etmişlerdir. Çetin $(2006$, s.74) ise yapmış olduğu kuramsal çalışmasında, güven ve sosyal sermaye kavramlarının toplumsal düzeyde ekonomik kalkınma aracı olarak irdelemiştir. Çalışmada, toplumsal bir kalkınmadan söz edilebilmesi için öncelikle sosyal sermaye yapısının gelişmiş olması gerektiği belirtilmiş, sosyal sermayenin oluşumunda etkili olan faktörler arasında ise güven kavramının önemi değerlendirilmiştir (Çetin, 2006, s.75). Çalışmada elde edilen çıkarımlara göre, güven ve sosyal sermaye arasındaki ilişkiler oldukça etkili ve olumlu yönlüdür. Öte yandan, sosyal sermaye konusunda yapılan bazı çalışmalarda güvenin sosyal sermaye ile benzeştiğinden, birbirinin aynı kavramlar olarak kullanılabileceğinden ya da sosyal sermayenin alt kavramlarından birinin güven olabileceğinden söz ettikleri gözlenmektedir. Örneğin, Norris (2002, s.19) çalışmasında ülkelerin sosyal sermaye düzeylerini hesaplarken bireylerin genelleştirilmiş güven düzeylerini endekse dahil etmiştir. Bu açıdan, Norris'in çalışmasının güveni sosyal sermayenin bir alt boyutu olarak gördüğü söylenebilmektedir. Ancak, bu çalışmada, Norris'in (2002) argümanından farklı olarak güven kavramı sosyal sermaye yapısı ile benzer veya eşanlamlı olarak görülmemekte, güvenin sosyal sermayenin bir öncülü olma niteliği değerlendirilmektedir. Türkiye'de Gerşil ve Aracı (2012, s.40) tarafından yapılan çalışmada vurgulandığı gibi, sosyal sermaye olgusunun en önemli önceli güven unsurudur. Bu çalışmada da öne sürüldüğü gibi, güven unsuru, bir yandan çalışanların aidiyet duygusunu ve motivasyonunu arttırarak işgücü performansını olumlu yönde etkilemekte, diğer yandan örgütsel düzeyde içsel sosyal sermaye yapısının gelişimini sağlayabilmektedir. Güven unsurunun bulunmadığı işletmelerde, işgücü performansından ve işyeri verimliliğinden söz edilemez. Özetle, bu çalışmada, önceki bölümümüzde de öne sürüldüğü gibi, sosyal sermayenin bir öncülü olarak örgütsel güven algısının önemli bir role sahip olabileceği üzerinde durulmaktadır. Bunun yanında, Ekinci (2012) tarafından da belirtildiği gibi, açık sistem özelliği gösteren eğitim sistemi ve okullar açısından sosyal sermayenin en önemli işlevini, okul toplumunu oluşturan bireyler ve gruplar arasında işbirliği imkânlarını arttıran bir potansiyel olarak değerlendirmenin uygun bir yaklaşım olacağı düşünülmüştür. Bu bakımdan bu çalışmada sosyal sermayenin, bireyler ve gruplar arası ilişki ve etkileşimi olumlu yönde geliştirdiği ve okulların sosyal sermayesini arttırmada bir potansiyel kaynak olarak işlev gördügü öncülünden yola çıkılarak örgütsel güven kavramı bir bağımsız değişken olarak incelenmiş̧ir.

Bu bağlamda, literatürde yer alan kuramsal ve ampirik çalışmalarda görüldüğü gibi, güven ve sosyal sermaye arasındaki güçlü bağı ortaya koymaları bakımından önemli birer referans kabul edi- 
lebilmektedir. Bu noktada, örgütlerde inşa edilen güven ve güven ilişkilerinin, ortak hedefler ve beklentilerin gerçekleştirilmesinde oldukça etkili olup sosyal sermayenin oluşturulmasında önemli bir katkıya sahip olabileceği görülmektedir.

Buraya kadar olan anlatımlarda görüldüğü gibi, güvene dayalı ilişkilerin kurulmasında; ekonomik ve toplumsal hayatta tüm işlerin sağlıkı bir şekilde yürütülmesinde sosyal sermeye önemli bir rol oynamakta ve gücünü kültürel köklerden almaktadır. Buna bağlı olarak bir toplumda var olan sosyal sermaye birikiminin, o toplumda ki bireylerin birlik oluşturma oranlarına bağı olarak gelişim gösterdiği söylenebilmektedir (Gerşil ve Aracı, 2011). Grup oluşturma ve birlikte çalışabilme yetenekleri de, paylaşılan kurallar ve güven sayesinde gelişmektedir (Şan, 2007). Sargut (2006) tarafından da vurgulandığı gibi, toplumdaki bireylerin birbirlerine ve kurumlara karşı duyduğu güven, sosyal sermaye birikimi açısından oldukça önemlidir. Bu bağlamda, Türk toplumu üzerinde gerçekleştirilmiş olan görgül araştırma sonuçlarına ve Türkiye üzerine yapılan bu değerlendirmelere dayanarak, içsel yaklaşımın sosyal sermayeyi güvenle özdeşleştirmekte olduğu gözlenmektedir. Bu nedenle güven kavramıyla sosyal sermaye arasında ilişki olabileceği ileri sürülerek, bu çalışmanın araştırma temelini oluşturan birinci ve ikinci sorunsalı ve bu sorunsalın analizine zemin teşkil eden ilk hipotezi aşağıdaki gibi önerilmektedir.

Soru 1: Bireylerin çalışmakta oldukları örgüte yönelik olarak algıladıkları sosyal sermaye düzeyi nedir?

Soru 2: Bireylerin çalıştıkları örgüte, yöneticilerine ve birbirlerine karşı duydukları güven düzeyi ile algıladıkları sosyal sermaye düzeyleri arasında bir ilişki var mıdır?

Hipotez 1: Bireylerin algıladıkları örgütsel güven ile algıladıkları sosyal sermaye yapısı arasında anlamlı bir ilişki vardır.

Hipotez 1a: Bireylerin çalıştıkları örgüte karşı duydukları güven ile algıladıkları sosyal sermaye yapısı arasında anlamlı bir ilişki vardır.

Hipotez 1b: Bireylerin yöneticilerine karşı duydukları güven ile algıladıkları sosyal sermaye yapısı arasında anlamlı bir ilişki vardır.

\subsection{Sosyal Adalet ve Sosyal Sermaye iliş̧kisi}

Büyüklüğü fark etmeksizin tüm sosyal sistemlerde "adalet" algısının, sürekliliğin, refahın ve bireylerin beklentilerinin karşılanabilme derecesiyle ilişkili olup, toplumsal (makro/sosyolojik) ve psikosoyal (mikro/bireysel-örgütsel) düzeylerde pek çok kavram ve olgu ile etkileşim içerisinde olduğu bilinmektedir. Üyeleri aracılığıyla hedeflerini gerçekleştirerek hayatta kalma mücadelesi veren örgütler açısından adaletin önemi de bu noktada açıklık kazanmaktadır. Bireylerin dahil oldukları her düzlemde (aile, okul, arkadaş grupları, işyeri, ülke, vs.) adalet arayışı içinde olmaları, adalet kavramını örgütsel davranış açısından da incelenmeye değer kılmaktadır ki, konu literatürde sıklıkla çalışılmaktadır. Sosyal bilimciler, çalışanların kişisel doyumu ve bununla bağlantılı olarak örgütlerin amaçlarını 
gerçekleştirmedeki başarısı için, adalete ilişkin olumlu kanaatin temel bir gereklilik olduğunu belirtmektedirler (Greenberg, 1990, s.399).

Örgütsel bağlamda "Örgütsel adalet" kavramı ilk olarak 1987 yılında Greenberg $(1987$, s.10) tarafından, "çalışma ortamında adaletin rolünü" terimleştirmek amacıyla kullanılmıştır. Moorman'ın $(1991$, s.845) belirttiği gibi örgütsel adalet, "özellikli olarak, çalışanların işlerinde adil muamele görüp görmediklerini ne şekilde tayin ettikleri ve bu saptamalarının işle ilgili diğer değişkenleri nasıl etkilediği" sorununu ele almaktadır. Ployhart ve Ryan (1997, s.309) ise, örgütsel adaletin işle ilgili konularda insanların adaleti nasıl algıladıkları ve ne şekilde tepki verdiklerini ifade ettiğini öne sürmüştür. Örgütsel adalet kavramının sahip olduğu geniş kuramsal altyapı ve tanımlara ilaveten, bu kavramın ölçümlenmesi ile ilgili olarak da boyutları konusunda farklı yaklaşımlar bulunmaktadır. Yapılan literatür taraması, dağıtım adaleti, prosedür adaleti (işlemsel) ve etkileşim adaleti olmak üzere üç temel boyutun geniş ölçüde kabul gördügünü ve ampirik çalışmalarla da desteklendiğini göstermektedir (Colquitt, 2001, s.386; Colquitt, Greenberg ve Zapata-Phelan, 2005, s.5). Özetle, mevcut tanımlar ve ilgili literatür göz önünde bulundurulduğunda "örgütsel adalet", çalışanların işle ilgili olması gerektiğini düşündükleri ile gerçekleşenleri kıyaslamaları sonucunda tespit ettikleri farka bağlı olarak şekillenen örgütlerine ilişkin adalet algılarının bütünüdür (Karaeminoğulları, 2006, s.9). Bu noktada, hemen hemen tüm çalışmaların değindiği gibi, adalet, göreli bir kavramdır ve bu sebeple örgütsel adaletin normatif değil tanımlayıcı bir yaklaşım ile ele alınması uygun görülmüştür.

Bu çalışmada esas alınmış olan nokta ise adaletin örgütsel bağlamda dağıtımsal, işlemsel ve etkileşimsel boyutlarda nasıl algılandığı değil içinde bulunan örgütsel çevre içerisinde bireysel hak ve özgürlükleri, eşitlik, ödüllerin dağıtımı, bireysel yeteneklerin dikkate alınması gibi kavramları içine alan sosyal adalet bağlamında nasıl algılandığıdır. Bu anlamda sistemsel bir bakış açısıyla bakıldığında, örgüt bağlamında algılanan sosyal adaletin tıpkı örgüt kültürü-ulusal kültür ilişkisinde olduğu gibi aslında kolektif değerlendirmelerden etkilendiği tartışılabilmektedir. İçinde bulunulan toplumun kolektif bilinciyle birlikte örgütsel seviyede sosyal adalet algısı da yine toplumsal sosyal adalet algısının bir yansıması olabilecektir. Öyle ki, Miller (1999), sosyal adaleti hak etme, gereksinimler, yasal haklar ve eşitlik olarak kavramsallaştırmış, sosyal psikoloji ve örgütsel psikoloji yaklaşımlarıyla bu kavramların çalışma ortamındaki yansımalarını değerlendirmiştir. Miller (1999), sosyal adaletin bu unsurlarının örgütsel yaşamda da iz düşümlerinin olabileceğinden ve örgütteki sosyal adalet kapsamına giren bu unsurlara dair olumlu veya olumsuz değerlendirmelerin yine bireysel tutum ve iş sonuçlarına etki edebileceğinden söz etmiştir. Dinga (2014) ise yazmış olduğu kavramsal makale çalışmasında, sosyal adalet algısı örgütsel bağlamda ele almış ve örgütsel yaşamda algılanan sosyal adaletin bireylerin etkin iletişim ve katılım geliştirmeleri suretiyle çeşitli olumlu örgütsel sonuçlara etki edebileceğini öne sürmüştür. Bununla birlikte, örgütsel bağlamda ele alınan sosyal adaletin de, yine toplumsal bağlamda olduğu gibi kaynakların dağııımı, bireysel refah, sürdürülebilirlik, haklar ve kurallar önünde eşitlik gibi unsurlara yönelik değerlendirmeleri içinde aldığı çeşitli çalışmalarda ifade edilmiştir. Örneğin, Dolan'ın (2008) örgütsel düzeyde sosyal destek ve örgütsel düzeyde sosyal adalet algılarına yönelik çalışması, sosyal adaletin örgütsel adaletten ayrılan tüm bu karakteristik özellikleri ile incelenmesi bakımından dikkat çekici bulunmuştur. Tüm bu nedenlerle, Miller (2001) ve Jost 
ve Kay (2010) tarafından da işaret edildiği gibi, daha mikro açıdan bakılarak sosyal adaleti bir sosyal psikoloji kavramı olarak ele alıp örgütlerde çeşitli bireysel tutum ve davranışlar ile örgütsel sonuçlarla olan bağlantılarını incelemek mümkün görünmektedir.

Bu anlatımlara dayanarak, bu çalışmada kuramsal temellerini sosyolojik unsurlardan alması özelliği de göz önünde bulundurularak, sosyal adalet kavramı örgütsel adaletten farklı olarak ele alınmış ve kavramsal ve işe vuruk tanımlamaları aşığında örgütsel bağlamda incelenmiştir. Bununla birlikte, konu ile ilgili literatürde, örgütsel bağlamda ele alınan sosyal adalete yönelik ampirik bulguların da varlığı bu çalışmanın kuramsal tartışmasına ve kuramsal çerçevesine destek sağlamıştır. Bu sebeple, adalet, örgütsel adalet ve sosyal adalet kavramlarının ve örgütsel bağlamda ele alınışının açıklanabilmesi amacıyla sunulan bu ön bilgiler sonrasında, adalet ve sosyal adalet kavramları ve bu çaıışmada incelenmekte olan sosyal sermaye kavramı ile olan bağlantıları aşağıdaki bölümde tartışılacaktır.

Çalışmamızın önceki bölümünde de değinildiği gibi, adalet kavramı, sosyal sermaye gibi kuramsal ve felsefi temelleri oldukça geniş olan bir kavramdır. Adalet kavramı üzerine felsefi olarak ilk sistematik yaklaşımların Antik Yunan Dünyası'nda ele alınmış olduğu ve genel olarak Yunan düşüncesinde adalet, ahlâk ve hukuk kavramlarının bir arada değerlendirildiği bilinmektedir. Adaletin toplum ve devlet için önemini belirtmiş olan Aristoteles'in düşünceleri Roma Dünyası'nda geniş yer bulmuş, ahlâk, adalet ve hukuk kavramları birbirinden ayrı olarak vurgulanmaya devam etmiştir (Aslan ve Gülaçtı, 2013, s.204). Ortaçağ’daki adalet kavramına bakıldığında, Hristiyan düşüncesinde adalet kavramının, kamu yararına dönük olarak algılanmış olduğu ve toplumun yararını koruduğuna inanıdığı görülmektedir (Leon-Guerrero, 2010). 19. yüzyıl bakış açısıyla incelendiğinde, faydacı liberal geleneğin öncülerinden Mill'in (2000) köleler ve özgür insanlar, derebeyleri ve serfler, soylular ve sıradan insanlar, sermayedarlar ve emekçiler farklı zamanları yansıtan ama aynı hiyerarşik izleri taşıyan sosyal gerçekliklerin adaletsizliğe dönüşmüş hallerinin birer yansıması olduğunu öne sürdüğü gözlenmektedir. 20. yüzyıl düşünürlerinden ve kuramcılarından Rawls (1971) ise, "A Theory of Justice (Adalet Teorisi)" isimli kitabında, adalet teorisi üzerine açıklamalar ve tartışmalar getirerek, toplumsal işbirliğinin olmadığı bir durumda hiç kimsenin sosyal adalet taleplerinin olamayacağından çünkü bu tür taleplerin hak edilmemiş olduğundan söz etmiştir. Toplumsal işbirliği olmadığında, her birey yardım görmeden kendi çabasıyla elde ettiği şeyleri hak etmekte ve başka hiç kimse bu edinimler üzerinde adalet ile ilgili bir talepte bulunamamaktadır. Nozick (2000) de toplumsal işbirliğinin olmaması durumunda hiçbir adalet teorisine ihtiyaç olmamasının söz konusu olmayacağını ve toplumsal işbirliğinin olmadığı bir ortamda edinimlerin meşruluğunu sağlayabilmek üzere yetkisel adaletin uygulanmasının öne çıkacağını öne sürmüştür. Bu noktada, Nozick'in, Rawls'un aksine toplumsal işbirliğinin olmadığı bir durumun yetkisel adalet ile bağdaştığını ileri sürdüğü görülmektedir. Ayrıca, Nozick (2000, s.241), Rawls'un belirttiği toplumsal işbirliği nedeni ile paylaşımın sosyal adalet ilkesine göre yapılması gerektiği düşüncesini savunarak, sosyal adalet kavramının anlaşılmasına da zemin hazırlamıştır. Nozick'e (2000, s.242) göre, toplumdaki faydaların ve yükümlülüklerin dağılımını uygun bir şekilde yapabilmek için ilkeler setine yani sosyal adalet ilkelerine ihtiyaç vardır. Böylece, sosyal adalet ilkeleri, bireylerin toplumun temel kurumlarındaki haklarını ve görevlerini belirlemekte ve 
toplumsal işbirliğinin menfaat ve yükümlülüklerinin doğru bir şekilde dağıtımını ortaya koymaktadır (Nozick, 2000, s.242; Sağlam, 2007, s.46). Bu çalışmada da, Nozick'in (2000) sosyal adalet kavramı üzerine açıklamaları ve tanımlamaları esas alınmaktadır.

Öte yandan, kuramsal köklerini felsefe ve Antik Yunan Dünyası'ndan alarak günümüze dek her yüzyılda farklı disiplinlerde üzerinde durulmuş olan sosyal adalet kavramı, yönetim, örgüt ve davranış bilimleri literatüründe de yerini almıştır. Sosyal politika ve iktisadi bir bakış açısıyla değerlendirmeler yapan Van Wormer (2004), adaletsizliği çaresizlik, baskı, sindirilme ve eşitsizliğin doğal bir sonucu olarak görmüş, sosyal politikaların amacını ise, var olan bu adaletsizlikleri ortadan kaldırmak olarak ifade etmiştir. Gil (2006), adil toplumların bütün fertlerini eşit kabul etmesi ve herkese eşit haklar ve sorumluluklar yüklemesi gerektiğini öne sürmüştür. Riley (1998 Aktaran Topakkaya, 2006, s.96) ise, sosyal adaleti, ahlaki gereksinmelerin bir fonksiyonu olarak görmüş, bu ahlaki gereksinmelerin, güvenli bir toplumda yaşayabilmek için zorunlu olduğunu, yasa, gelenek ve göreneklerim de bu gereksinmeleri karşılayacağını belirtmiştir. Akalın (1998) sosyal adaleti, haklar, siyasal özgürlükler ve kanun önünde eşitlik, ödüller, her bireyin yeteneklerinin ve faaliyetlerinin dikkate alınması, ihtiyaçlar ile bireyin hayatını sürdürebilmesi için gerekli olanlar şeklinde açıklamıştır. Topakkaya (2006, s.97), sosyal adalet kavramının belli başlı iki farklı tanımından bahsetmiştir. Bu tanımlar çerçevesinde, pozitif hukuk açısından sosyal adalet kavramı, demokratik bir ülkenin olmazsa olmaz bir kuralı olan kanunlar karşısında herkesin eşitliği (hem bağlayıcılık hem de fırsat eşitliği anlamında) ilkesidir. Sosyolojik açıdan ise, üretim sürecinde ve üretim sonrasında paylaşımın mümkün olduğu kadar topluma yayııması ve toplum sağlığı açısından sosyal tabakalar arasında aşırı farklılaşmanın önüne geçmek için gerekli önlemlerin alınması olarak değerlendirilebilmektedir (Topakkaya, 2009, s.2). Sunal (2011, s.286) ise, sosyal adaletin en yalın anlatımla, nimet ve külfetlerin toplumda adil bir şekilde dağıtılması olduğunu ifade ederek, toplumda herkesin hakça bir paylaşım olduğu konusunda genel bir kanaatinin bulunması olarak tanımlamıştır. Genel anlamda güvenliğin en üst düzeye çıkarılabilmesi, herkese eşit haklar verilebilmesi ve maddesel kaynakların adaletli dağıtılabilmesi için, bir ideal kodun (yol gösterici kurallar) gerekli olduğu görüşü genel bir kabul görmüştür (Aslan ve Gülaçtı, 2013, s.204).

Miller (1999) ise, sosyal adaletin dört unsurunu şu şekilde kavramsallaştırmıştır: hak etme, gereksinimler, yasal haklar ve eşitlik. Miller, bir örnekten yola çıkarak sosyal adaleti bu dört unsurun dengede olduğu bir durum olarak tanımlamaktadır. Sosyal adaleti bu örnekte olduğu gibi dört unsuru olan bir durum olarak düşündügümüzde, birinci iş̧̧i alacağı parayı fazlasıyla hak etmiştir. íkincinin ise alacağı paraya diğer ikisinden çok daha fazla ihtiyacı vardır, çünkü çalışmasını ve karnını doyurmasını engelleyen hastalığından kurtulması gerekmektedir. Üçüncü iş̧̧i ise başta yapılan anlaşma gereği, bu sözleşmeden kaynaklanan yasal bir hakkı olduğu için parayı alacaktır. Her birinin aldığı ücretin birbirinin aynı olduğu düşünüldüğünde, bu durumda mutlak eşitlik sağlanmıştır. Süreç işleyişi ve doğurduğu sonuç bakımından mutlak eşitlik esasının gereklerini yerine getirmiştir (Sunal, 2011, s.287). Ancak, Miller'in (1999) sözünü ettiği, sosyal adaleti sağlamanın zorluğudur. Çünkü saydığı dört unsurun dengede bulunduğu bir durumu sağlamak, her zaman mümkün olmayabilir. Çünkü hak etme ve gereksinim duyma gibi kavramlar, ölçülmesi mümkün olmayan, kişiden kişiye değişen 
ve üzerinde herkesin uzlaşmaya varamadığı, felsefi yönleri çok daha ağır basan kavramlardır. Oysa yasalarla sağlanan siyasal eşitliklerin veya nicel yönü çok ağır basan ekonomik eşitliklerin ne ölçüde gerçekleştiğini görmek daha kolaydır. Bununla birlikte, sosyal adalet kavramının aileden aileye, kişiden kişiye ve toplumdan topluma tarih içerisinde farklıık gösterebildiğine ve toplumdaki diğer sosyal ve iktisadi yapı değişkenleri ile doğrudan ilişkili olabileceğine dikkat çekilmiştir (Aslan ve Gülaçtı, 2013).

Bu noktada, Karagül ve Masca $(2005$, s.46) sosyal sermayenin arttırılmasında toplumdaki sosyal adalet sistemine ve örgütteki güven ortamına ilişkin olumlu yada olumsuz sorgulamaların bulunmasının etkili olabildiğini tartışarak sosyal sermaye oluşumunda adalet ve güven algısına vurgu yapmışlardır. Fukuyama (2000) tarafından da öne sürülmüş olduğu gibi, bireysel düzeyde ölçümlenen sosyal adalet, güven unsurlarındaki eksiklik bir dizi çözülmelerle sebebiyet vermekte ve sosyal sermaye üzerinde olumsuz etki yaratabilmektedir. Bu çalışmaların öne sürmüş olduğu ortak sonuç, sosyal adalet kavramının, genel olarak insanlar için yaşamda denge unsuru olarak algılanmakta olduğu ve her kurumda bireylerin sosyal adalete ilişkin inanç ve değerlendirmelerinin olumlu veya olumsuz bireysel tepkilerle karşılaşabileceğidir. Böylece, bireyin yeteneklerinin ve ihtiyaçlarının dikkate alınarak eşit haklara sahip olarak yaşamını sürdürmesi olarak kabul edilen sosyal adaletin yönetim ve davranış bilimleri literatüründe de ele alındığı araştırmalara rastlanmaktadır. Taştan ve Yılmaz (2008), eğitim örgütlerinde yaptıkları çalışma ile, örgütsel vatandaşlık ve örgütsel adalet konusunda ölçeğin uyarlama çalışmasını yapmışlar, Şahin (2008) dayanışma, adil davranma, başarı gibi belli değerleri benimseyen okul yöneticilerinin çok sınırlı kaynaklarla orta ve alt gelir grubundaki aile çocuklarına eğitim hizmeti sunarak etkili sonuçlara ulaşabileceğini ortaya koymuştur. Gewirtz (2006) eğitim sistemleri, eğitim politikaları ve eğitim kurumlarındaki uygulamaların sosyal adalet yönünden analiz edilebileceğini belirtmiştir. Polat (2007) eğitim politikalarının sosyal adalet açısından sonuçları konusunda yönetici ve öğretmen görüşlerini aldığı araştırması ile sosyal adaletin boyutlarını belirlemiş̧ir.

Öte yandan, sosyal adalet ve sosyal sermaye arasındaki bağlantıyı açığa kavuşturan ve görgül bulguların öne sürülmüş olduğu çalışmalara yeterince rastlanamamıştır. Ancak, bilindiği üzere, sosyal sermaye kavramının arkasındaki literatür, kendilerini bir topluluğun parçası olarak gören bireylerin, birbirleriyle daha verimli ilişkiler kurma eğiliminde olduklarını öne sürmektedir (Aydemir ve Tecim, 2012). Bu eğilimi besleyen, bireyleri motive eden ve sosyal sermaye yapısının geliştirilmesinde etkili olabilecek bir unsur olarak sosyal adalet algısının sosyal sermaye potansiyelinden söz edilebilmektedir. Ayrıca, literatürdeki göstergeler üzerinden sosyal adalet ve sosyal sermaye ilişkisi kendini oldukça açık bir şekilde ortaya koyabilmektedir. Adil değerler, sosyal ve kurumsal yapı ile ilgili adalet algısı, iyilik, arkadaşılı, örgüte ve geleceğe duyulan güven gibi maddi olmayan pozitif değerlerin toplumda oynadığı rolün ve toplumsal ve örgütsel düzeylerde sosyal sermaye yapısının oluşumunda etkisinin fazla olduğu belirtilmektedir (Karagül ve Masca, 2005:39; Bkz. World Bank, 2001²). Diğer

\footnotetext{
${ }^{2}$ World Bank (2001). Key Indicators of Other Economics. World Development Indicators.
} 
yandan, örgütlerde, sosyal ilişkilerin, sosyal bağlılığın ve sosyal sermaye yapısının etkinliği açısından, içinde bulunulan toplumdaki adalet sistemin iyi çalışmasının (Montada, 1998; Özmen, Arbak ve Özer, 2007; Helliwel, 2012) ve toplumdaki ve örgütteki sosyal adalete ilişkin değerlendirmelerin (Helliwel, 2012; Aslan ve Gülaçtı, 2013) öneminin oldukça büyük olduğu öne sürülmektedir. Bu bilgilere dayanarak, örgütlerde sosyal sermaye işleyişinin hızlandırıması ve geliştirilmesinde sosyal adalet kavramına ilişkin algıların işlevsel ortaklığı olabileceği beklenebilmektedir. Kendilerini bulunduğu topluma ve örgüte karşı daha bağlı ve sorumlu hisseden bireylerin algıladığı sosyal adalet üzerinden karşılıklı yardımlaşma ve dayanışma ağlarını inşa edebilme becerisinin artabileceği ve bu anlamda bir sosyal sermaye unsuru olarak sosyal adaletin rolünün belirginleşebileceği düşünülmektedir.

Dinga (2014) tarafından yapılan kavramsal bir çalışmada, sosyal adalet algısının bireylerin iletişim, katılım ve işbirliği geliştirmelerine etki ettiğinden söz edilmiş, bu etkiler yoluyla örgütlerde sosyal sermaye gelişimine katkıda bulunduğu belirtilmiştir. Aynı zamanda, sosyal adaletin var olduğu bir sistemde kaynakların eşit dağılımına yönelik algının, bireysel refahın ve sürdürülebilirliğin de doğru orantılı olarak artabildiği ve böylece yine sosyal sermayenin güçlenmesinde etkili olduğu vurgulanmıştır (Dinga, 2014, s.250). Öte yandan, Dolan (2008, ss.114-116), sosyal destek, sosyal adalet ve sosyal sermaye kavramlarını birbirini tamamlayan bir üçlü zincir olarak görmüş ve algılanan sosyal desteğin sosyal adalete yönelik değerlendirmeleri pekiştirebileceğini, sosyal adaletin ise gerek örgütsel gerekse de toplumsal düzeyde sosyal sermaye birikiminin artmasında etkili olduğunu belirtmiştir. Bununla birlikte, sosyal adalet kavramının Eckerd, Campbell ve $\operatorname{Kim}(2013$, s.4) tarafından çevresel adalet ifadesi ile de eşdeğer olarak kullanıldığı ve bireylerin içinde bulundukları toplumdaki hak, özgürlükler, kaynakların dağılımı ve bilgiye erişim gibi değerlendirmelerinden oluştuğunun ifade edildiği göze çarpmaktadır. Eckerd ve arkadaşlarının $(2013$, s.7) yaptığı açıklamalara göre, sosyal adalet algısı bir toplumdaki kolektif hareket, grup davranışları ve bilgi paylaşımı süreçlerini doğrudan etkileyebilmekte ve bu yönüyle pozitif algılanan bir sosyal adalet unsuru toplumsal düzeyde sosyal sermaye gelişiminde önemli bir role sahip olabilmektedir. Adalet ve sosyal sermaye arasındaki ilişkiler incelendiğinde, kuramsal çalışmalarla birlikte ampirik çalışmalara sınırlı sayıda da olsa rastlanmaktadır. Özellikle Akbari, Sharafi ve Vatandost (2012) tarafından bir eğitim kurumunda yapılan çalışmada örgütsel adalet ve sosyal sermaye ilişkisi araştırılmıştır. Yapılan korelasyon ve regresyon analizleri neticesinde, dağıtımsal, işlemsel ve etkileşimsel adalet boyutlarından oluşan örgütsel adalet algısının kurumdaki sosyal sermaye yapısına yönelik algı ile anlamlı ve pozitif yönde ilişkili olduğu ve örgütsel adaletin sosyal sermayeyi anlamlı ve pozitif olarak açıkladığı belirlenmiştir (Akbari vd., 2012, s.460).

Böylece, yukarıda ele alınmış olan kuramsal altyapı ve literatür çalışmalarından elde edilen bilgiler doğrultusunda, içsel sosyal sermaye olgusunun, ona yön veren bireylerin örgüte ve yöneticilere duydukları güvene ve sosyal yapı ve kurumlara ilişkin sosyal adalet algısına göre şekillenebileceği beklenebilmektedir. Söz konusu değişkenler arası ilişkilerin Türk toplumu bağlamında değerlendirilmesine yönelik gerçekleştirilen bu araştırmada yanıtlanması beklenen üçüncü sorunsal ve bu sorunsalın analizine zemin hazırlayan ikinci hipotez aşağıdaki gibi önerilebilmektedir.

Soru 3: Bireylerin sosyal adalet algısı düzeyi ile algıladıkları sosyal sermaye düzeyleri arasında bir ilişki var mıdır? 
Hipotez 2: Bireylerin sosyal adalet algısı düzeyi ile algıladıkları sosyal sermaye yapısı arasında anlamlı bir ilişki vardır.

Yapılan literatür çalışmasına ve konu ile ilgili önceki bulgulara dayanarak önerilen kuramsal araştırma modeli (Şekil 1) aşağıda sunulmaktadır.

Şekil 1. Araştırmanın Kuramsal Modeli

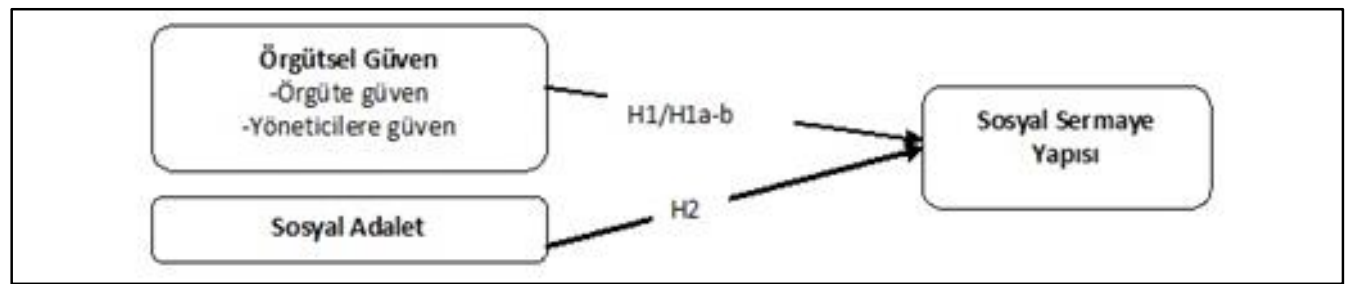

Yukarıda belirtilmiş olan araştırma sorularına ve önerilen hipotezlerin test edilmesine yönelik olarak gerçekleştirilmiş olan araştırmanın metodu ve elde edilen bulgular çalışmanın ilerleyen bölümünde aktarılmaktadır.

\section{Araştırma Metodolojisi}

Çalışma ortamındaki güven düzeyi ve bireylerin sosyal adalet algıları ile bulundukları örgüte yönelik sosyal sermaye düzeyine ilişkin değerlendirmeleri arasındaki ilişkiyi ortaya koymak ve güven ve sosyal adalet unsurlarının sosyal sermaye düzeyini belirleme potansiyelini analiz etmek üzere bir araştırma modeli oluşturulmuştur. Bunun için modelin çatısını oluşturan konuların araştırmasına yönelik üç araştırma problemi çerçevesinde iki ana ve iki alt hipotez test edilmiştir. Buna göre bireylerin çalıştıkları örgüte, yöneticilerine ve birbirlerine karşı duydukları güven düzeyi ile buradan ulaşılacak genel güven düzeylerini, algıladıkları sosyal adalet ve sosyal sermaye düzeylerini ortaya koymaya yönelik sorulan anket sorularına verilen cevapların analizi yapıımıştır.

\section{1. Araştırmanın Evren ve Örneklemi}

Geçmişte ya da hâlen var olan bir durumu var olduğu şekliyle betimlemeyi amaçlayan araştırmalar, tarama modeline göre düzenlenmiş araştırmalar olarak tanımlanmaktadır (Karasar, 2003). Bu çalışmada da sosyal sermaye, güven ve sosyal adalet konularına ilişkin öğretmenlerin ve eğitim örgütü yöneticilerinin görüşleri belirlenmeye çalışıldığından var olan bir durum ortaya konulmaya çalışımıştır. Bu doğrultuda, bu araştırma tarama modelinde desenlenmiş, tanımlayıcı ve kesitsel nitelikte bir araştırmadır. Araştırmaya katılan öğretmen ve yöneticilerin seçiminde, araştırmacının araştırmasını yürütebilmek için o an içinde ulaşabildiği katılımcıları araştırmasına dâhil ettiği uygun örnekleme yöntemi kullanılmıştır (Cohen, Manion, ve Morrison, 2007; Wallen ve Fraenkel, 2001). Bu yöntem ile gerçekleştirilen araştırma İstanbul'da Avrupa ve Anadolu yakasında bulunan kamu eğitim kurumlarında gerçekleştirilmiştir. Yapılan literatür araştırmasında, eğitim kurumlarında sosyal sermaye, güven ve sosyal adalet kavramlarının kısmen araştııımış olduğu görülmekle birlikte bu kav- 
ramların bir arada ele alarak güven ve sosyal adalet algılarının sosyal sermayeyi ne şekilde açıklamakta olduğunu tespit etmiş olan çalışmalara rastlanamamıştır. Eğitim kurumları açısından sosyal sermeye ve güven kavramları üzerine yapılan incelemelerde, sosyal sermaye düzeyinin ve güven algısının azaldığını ortaya koyan (Putnam, 2004; Ekinci, 2012) ve sosyal sermaye yapısı ile güven unsurunun eğitim kurumlarındaki önemini tartışan (Stanton-Salazar ve Dornbusch, 1995; TschannenMoran ve Hoy, 1998; Lee ve Croninger, 2001; Beaulieu, Israet ve Hartless, 2001; Bryk ve Schneider, 2002; Töremen, 2002; Karagül ve Masca, 2005; Toprak ve Bozgeyikli, 2011; Ekinci, 2012; Şimşek, 2013; Özmen vd., 2014) yerli ve yabancı çalışmalar bulunmaktadır. Özellikle, sosyal adalet algısı kavramsal olarak birçok çalışmada incelenmesine rağmen, yönetim, organizasyon ve örgütsel davranış literatüründe yeterince ele alınmadığı göze çarpmıştır. Bir bütün olarak da, örgüte, yöneticilere ve çalışma arkadaşlarına duyulan güven ve sosyal adalete ilişkin algının örgütün sosyal sermaye düzeyi ile ilgili değerlendirmeleri ne derece ve ne yönde etkileyebileceği henüz yeterli düzeyde saptanamamıştır. Bu nedenle, çalışmada yer alan kavramların eğitim kurumlarında öğretmen ve yönetici olarak görev yapmakta olan bireyler ve eğitim kurumları açısından anlamlı olacağı varsayımından hareketle kamu ve özel statülü eğitim kurumları araştırma kapsamında yer almıştır.

Araştırmanın genel evrenini, 2013-2014 eğitim-öğretim yılında İstanbul ili Avrupa ve Anadolu Yakasında bulunan kamu ve özel statülü ilköğretim ve liselerde çalışmakta olan öğretmen ve idareciler oluşturmaktadır. Araştırmanın örneklemini ise evrenden basit seçkisiz örnekleme yöntemiyle seçilen 15 ilköğretim okulunda ve 11 lisede çalışan 510 öğretmen ve idareci oluşturmaktadır. Örneklemin tespiti amacıyla, okul isimlerinin listesi il milli eğitim müdürlüğünden temin edilmiş ve her iki yakada 3 ayrı ilçe olmak üzere en az üç okul olmak üzere örnekleme alınacak okullar listeden seçilmiştir. Örneklem büyüklügü hesaplanırken evren standart sapması bilinmediğinden daha önce yapılmış araştırmadan (Ekinci, 2008; Ekinci, 2012) s=1 olarak tahmin edilmiş, \%95 güven düzeyi ve 0.1 hata payı dikkate alınmıştır. Bu durumda yeterli örneklem büyüklüğüne ulaşıldığına karar verilmiştir (Büyüköztürk, Çakmak, Akgün, Karadeniz ve Demirel, 2008). Katılımcılardan geriye dönen veri toplama araçlarından eksik veya yanlış doldurulanların çıkarılmasıyla 502 ölçme aracı değerlendirmeye alınmıştır. Yapısal eşitlik modelleri, kovaryans matrisindeki farkların anlamlılığına ve katılımcı sayısına duyarlı testlere dayandığı için, bu tür modeller kurulurken katılımcı sayısının 200'den fazla olması gerektiği belirtilmektedir (Bayram, 2010, ss.47-51; Kline, 2011, ss.46-73). Araştırmanın katılımcı sayısı 502 kişiden oluştuğu için bu sayının araştırmanın amacı ve istatistiksel çözümleme için uygun olduğu görülmektedir.

Araştırmaya katılan öğretmenlerin ve idarecilerin 265'i kadın, 237'si ise erkek öğretmenlerden oluşmaktadır. Katılımcıların \%18'i “30 ve daha az" yaş grubunda, \%62'si “31-40 yaş” grubunda ve \%20'si ise "41 ve üzeri” yaş grubundadır. Görev türü açısından katılımcıların \%22'si “idareci", \%78'i "öğretmen" olarak görev yapmaktadır. Çalışma süresi açısından katıımcıların \%38'i "10 yıl ve daha az" çalışma süresine sahipken, $\% 50$ 'si "11-20 yıl” ve \%12'sı ise "21 yıl ve üzeri” çalışma süresine sahiptir. 


\section{2. Veri Toplama Araçları}

Bu araştırmada gerekli bilgileri toplamak amacıyla anket çalışması yapılmıştır. Anket sorularının hazırlanmasında, Kişisel Bilgi Formu, araştırmanın bağımsız değişkenlerinin ölçmek amacıyla Örgütsel Güven Ölçeği ve Sosyal Adalet Algısı Ölçeği kullanılmıştır. Araştırmanın bağımlı değişkenini ölçmek amacıyla sosyal sermaye ölçeğinden yararlanılmıştır. Ölçeklerle ilgili bilgiler aşağıda sunulmaktadır.

Sosyal Sermaye Ölçeği: Bu çalışmada kullanılmış olan Sosyal Sermaye Ölçeği Nahapiet ve Ghoshal (1998), Moran ve Ghoshal (1996) ve Tsai ve Ghoshal (1998) çalışmalarından derlenmiştir. Ölçekte Yapısal, ilişkisel ve Bilişsel sosyal sermaye boyutlarını ölçmek üzere oluşturulan 26 madde yer almaktadır. Ölçeğin güvenilirlik ve geçerlilik analizi Göksel, Aydıntan ve Bingöl (2010, s.94) tarafından gerçekleştirilmiş olup Türkiye'de farklı sektörler yapılan çalışmalarda kullanılmıştır. Yapısal boyut (9 madde), "iletişim ağları", "iletişim ağ yapıları" ve "uygun örgüt anlayışı” alt boyutlarıyla; bilişsel boyut (4 madde), "ortak dil” ve "ortak hikâyeler" alt boyutlarıyla ve ilişkisel boyut (13 madde), "duygusallığa dayalı güven”, "normlar”, "zorunluluk" ve "özdeşleşme” alt boyutları ile açıklanabilmektedir. Söz konusu ölçek, Turgut ve Beğenirbaş (2013) tarafından sağılık sektöründe yapılan bir araştırmada kullanılarak doğrulayıcı faktör analizi sonuçlarının kabul edilebilir düzeyde olduğu raporlanmıştır. Bununla birlikte, Özmen ve arkadaşlarının (2014) eğitim kurumlarında öğretmen ve okul müdürleri üzerinde yaptıkları araştırma kullanılmış ve ölçeğin doğrulayıcı faktör analizi sonuçlarına göre uyum değerlerinin kabul edilebilir seviyede olduğu ortaya çıkmıştır. Türkiye'de daha önceki çalışmalarda $5^{\prime}$ li Likert tipinde hazırlanmış olan ölçek, bu çalışmada 6'ı Likert tipi derecelendirme ile kullanılmıştır. Derecelendirmedeki ifadeler "1=Kesinlikle katılmıyorum", "2=Çok fazla katılmıyorum", "3=Pek katımıyorum", "4=Biraz katılıyorum", "5=Oldukça katılıyorum", "6=Kesinlikle katılıyorum" şeklindedir. Katılımcılardan maddeleri çalıştıkları okulu düşünerek kendilerine göre en uygun seçeneği işaretleyerek cevaplamaları istenmiştir. Ölçek maddelerinin içerik geçerliliği araştırmacı ve Örgütsel Davranış alanında uzmanlığı bulunan bir öğretim üyesi tarafından incelenmiş ve gerekli görülen maddelerde uyarlama ve düzenlemeler yapılmıştır. Araştırmada yer alan Sosyal Sermaye Ölçeği maddeleri aşağıdaki Tablo 1'de sunulmaktadır. Çalışmada ölçeğin geçerliğini test etmek için doğrulayıcı faktör analizi (DFA) yapılmış ve iç tutarlılık katsayıları değerlendirilmiştir. DFA sonuçlarına göre sosyal sermaye ölçeğinin faktör yüklenimleri ve bu faktör yüklenimlerinin istatistiksel olarak anlamlı olup olmadıkları incelenmiştir. Yapılan analizde, yordama güçleri anlamlı olmayan maddelere rastlanmamıştır. Literatürde en yaygın kullanılan uyum indekslerinin referans aralıkları (Kline, 2005, s.134; Hooper, Coughlan ve Mullen, 2008, s.55) ve ölçme modellerine ait uyum iyiliği değerleri Tablo 4'de sunulmuştur. 
Seçil BAL TAŞTAN

Tablo 1. Sosyal Sermaye Ölçeğinin Maddeleri

Çalıştığım kurumda....

1. bilgilerimizi diğerleriyle paylaşabileceğimiz iletişim kanalları mevcuttur.

2. iletişim kanalları başkalarının sahip olduğu bilgilere erişimime olanak sağlamaktadır.

3. iletişim kanalları farklı birim ve kişilerde mevcut olan bilgilerin paylaşılmasına olanak sağlamaktadır.

4. iletişim kanalları farklı birim ve kişilerde mevcut olan bilgilerin dağıtılmasına olanak sağlamaktadır.

5. iletişim sistemi farklı birim ve kişilerden gelen bilgilerin diğer kişilere zamanında iletilmesine olanak sağlar.

6. iletişim ağı, ağ içinde bulunan kişilere bilgilerini paylaşma ve dağıtma olanaklarından haberdar olma fırsatı sağlar.

7. iletişim kanalı yoğun miktarda bilgiye ve bilgi paylaşımını gerçekleştirecek çok sayıda kişi ve birime sahiptir.

8. iletişim kanalı, bilgisini paylaşmak isteyen kişi ve birimlerin kolayca iletişim ağına katılmasına olanak sağlar.

9. örgütsel anlayış, farklı bireysel ve kültürel değerlere dayalı iletişim ve ilişkilerin oluşmasına olanak sağlamaktadır.

10. birbirimizi anlamamızı ve iletişime geçmemizi kolaylaştıracak ortak terimler, ifadeler ve sözlerden oluşan bir dil kullanırız.

11. kullandığımız ortak dil sahip olunan ve paylaşılan bilgileri elde etmede, yorumlamada ve anlamada etkinlik sağlar.

12. kullandığımız ortak dil, mevcut bilgilerden yeni bilgiler elde edilmesinde kolaylık sağlar.

13. anlatılan başarı hikâyeleri; bireyler ve birimler için bilgi ve değerlerin yaratılmasında, paylaşıımasında ve saklanmasında yol gösterici olur.

14. iş arkadaşlarım ile paylaşımcı bir ilişkimiz vardır. Fikirlerimizi, duygularımızı ve ümitlerimizi serbestçe paylaşabiliriz.

15. işle ilgili yaşadığım zorlukları iş arkadaşlarımla özgürce konuşabilirim ve onlar da beni dinlemek ister.

16. Eğer iş arkadaşlarımdan birileri bir yere transfer edilirse hem onlar hem biz yalnızlık hissederiz.

17. Eğer iş arkadaşlarımla sorunlarımı paylaşırsam, yapıcı ve ilgili bir şekilde tepki vereceklerdir.

18. İ̧ arkadaşlarımla ilişkilerimizde birbirimize belirgin ölçüde duygusal yatırımlar yapıyoruz.

19. takım çalışmasını ve yardımlaşmayı destekleyen bir anlayış vardır.

20. iletişime ve bilgi paylaşımına isteklilik ve açıklık paylaşılan bir değerdir.

21. eleştirilere ve farklı fikirlere açıklık, paylaşılan bir değerdir.

22. yazılı olmayan kurallar bilgi paylaşımını desteklemektedir.

23. iletişime, bilgi paylaşımına isteklilik ve açıkık beni benzer şekilde davranmaya zorunlu kılar.

24. paylaşılan değerleri kendi değerlerimle uyumlu buluyorum. 
25. kendimi bir bütün olarak görebiliyorum.

26. iletişime, bilgi paylaşımına isteklilik ve açıklık değerleri beni de bu yönde davranmaya sevk ediyor.

Örgütsel Güven Ölçeği: İkinci bölümde yönetici ve öğretmenlerin örgütsel güven algılarını belirlemek amacıyla Nyhan ve Marlowe (1997) tarafından geliştirilen ve Demircan (2003) tarafından Türkçe'ye adapte edilen ve Eğriboyun (2013) tarafından geçerlilik ve güvenilirlik analizleri yapılmış olan Örgütsel Güven Ölçeği kullanılmıştır. Bu çalışmada, ölçekte yer alan bazı maddeler araştırmacı ve örgütsel davranış alanında uzmanlığa sahip olan bir öğretim üyesi tarafından yapılan içerik geçerliliği değerlendirmeleri sonucunda uyarlanmıştır. Araştırmada yer alan Örgütsel Güven maddeleri aşağıdaki Tablo 2'de sunulmaktadır.

Tablo 2. Örgütsel Güven Ölçeğinin Maddeleri

Çalıştığım kurumda yöneticimin ve/veya idarecilerimizin...

1. işindeki kritik esaslar konusunda teknik olarak yeterli olduğuna dair güvenim yüksektir.

2. işi konusunda doğru kararlar alacağına dair güvenim oldukça yüksektir.

3. görevinden ayrılmayacağına dair güvenim yüksektir.

4. işini kabul edilebilir seviyede anladığına dair güvenim yüksektir.

5. işini uygun biçimde yapabileceğine dair güvenim yüksektir.

6. bana bir şey söylediği zaman söylediklerinin doğruluğuna dair güvenim yüksektir.

7. işini sorunsuz şekilde yapacağına dair güvenim yüksektir.

8. işini dikkatlice yapacağına dair güvenim yüksektir.

Çalıştığım kurumda...

9. bana adil şekilde davranılacağına dair güvenimin derecesi yüksektir.

10. yöneticiler ve öğretmenler arasındaki güven düzeyinin derecesi tamdır.

11. birlikte çalıştığım meslektaşlarım arasındaki güven düzeyinin istenilen esaslarda olmasının derecesi yüksektir.

12. birbirimize güvenebilme düzeyimizin derecesi yüksektir.

Ölçme aracının güvenirlik, açıklayıcı faktör analizi ve geçerlilik testleri Nyhan ve Marlowe (1997) tarafından yapılmış ve iç tutarlıık katsayısı (Cronbach Alpha) $\alpha=.96$ olarak hesaplanmıştır. Bu değer, istatistik alan yazında yüksek derecede güvenirliğin bir göstergesidir. Örgütsel Güven Ölçeği; yöneticiye güven ve örgüte güven olmak üzere iki alt boyuttan oluşan 12 maddelik bir ölçme aracıdır ve örgütsel güveni duygusal, bilişsel ve planlanmış davranış olarak değerlendirmektedir. Yöneticiye güven alt boyutu 8 maddeden oluşmakta ve 1-8'inci maddeleri ihtiva etmektedir. Örgüte güven alt boyutu ise 4 maddeden oluşmakta ve 9-12'nci maddeleri kapsamaktadır. Ölçme aracı "1=Kesinlikle katılmıyorum", "2=Çok fazla katılmıyorum", "3=Pek katılmıyorum", "4=Biraz katılıyorum", "5=Oldukça katılıyorum", "6=Kesinlikle katılıyorum" şeklinde Likert tipi bir derecelendirmeye sahiptir. Bu ölçek daha önce Türkiye'de eğitim kurumlarında öğretmenler üzerinde yapılan bir araştırmada (Ĕgriboyun, 2013, s.105) kullanılmış olup, yöneticiye duyulan güven boyutunun iç tutarlılık katsayısı $\alpha=$ .895 olarak ve örgüte duyulan güven boyutunun iç tutarlık katsayısı $\alpha=.851$ olarak hesaplanmıştır. 
Bu çalışmada, ölçeğin geçerliğini test etmek için doğrulayıcı faktör analizi (DFA) yapılmış ve iç tutarlılık katsayıları değerlendirilmiştir.

Sosyal Adalet Algısı Ölçeği: Bu çalışmada kullanılmış olan Sosyal Adalet Ölçeği kavram ile ilgili kuramsal ve felsefi metinlerden yararlanılarak araştırmacı tarafından oluşturulmuştur. Öncelikle literatürde sosyal adalet kavramı üzerine yapılan çalışmalar incelenmiş, kavramın içeriği doğrultusunda ifadeler oluşturulmuştur. Bu ifadelerin oluşturulmasında literatürdeki sosyal adalet kavramının kuramsal açıklamalarını yapan yabancı ve yerli çalışmalar referans alınmıştır (örn. Frankena, 1962; Rawls, 1971; Feinberg, 1973; Walzer, 1983; Elster, 1992; Miller, 1999; Nozick, 2000; Harvey, 2001; Kalkışım, 2013; Tuncay ve Erbay, 2006; Sağlam, 2007; Alp ve Karakaş, 2008; Topakkaya, 2009; Sunal, 2011). Aynı zamanda, bu çalışma, yönetim ve örgüt bilimleri ekseninde gerçekleştirildiği için, kavramın mahiyetinin ve ölçümlenmesinin de bu bağlamda sağlanması gerekli görülmüş ve sosyal adalet kavramını sosyal psikoloji ve yönetim bilimleri açısından irdeleyen çalışmalara başvurulmuştur. Bu noktada, sosyal adalet kavramının işe vuruk tanımlarının ortaya konmasında özellikle Miller (2001) ve Deutsch'un (1999) çalışmaları ve Jost ve Kay (2010) tarafından yazılan "Social Justice: History, Theory, and Research (Sosyal Adalet: Tarih, Teori ve Araştırma)" başlıklı eserinden yararlanımıştır. Bununla birlikte, Miller'in (2001) "The Handbook of Social Psychology (Sosyal Psikoloji El Kitabı)" isimli kitabında sosyal adalet kavramının bir kitap bölümü olarak yer alması oldukça dikkat çekici bulunmuştur. Bu nedenle, sosyal adaleti bir sosyal psikoloji kavramı olarak ele alıp örgütlerde liderlik, sosyal yapı, sosyal ilişkiler ve politik davranış gibi kavramlarla ilişkilerini değerlendirmiş olan Miller (2001, s.528) bu çalışmanın ölçüm aracında yer alan maddelerin oluşturulmasında katkı sağlamıştır. Son olarak, Aslan ve Gülaçtı (2013) tarafından üniversite öğrencilerinin sosyal adalet kavramının tanımlanmasına ilişkin görüşlerini incelediği çalışmasında uygulamış oldukları ölçüm aracı da incelenerek, madde havuzu oluşturulmuştur. Toplamda oluşturulmuş olan 20 adet soru yapılan bir ön araştırma ile 25 öğretmen, 20 sağlık personeli, 20 özel sektör çalışanı ve 15 üniversite lisansüstü öğrencisi olmak üzere toplam 80 kişi üzerinde denenmiştir. Ölçeğin Keiser-Meyer- Olkin analiz sonucu ve Barlett testi anlamlılık düzeyi $(p=.000)$ esas alınarak değerlendirmeler yapılmıştır. Yapılan ön testte ölçeğin iç tutarlılık katsayısı $\alpha=.859$ olarak hesaplanmıştır. Varimax rotasyonlu faktör analizi sonucunda, sosyal adalet maddeleri "toplumsal eşitlik" ve "adil ilişkiler sistemi" adı verilmiş olan iki faktör altında toplanmış olduğu gözlenmiştir. Birinci faktör dokuz maddeden oluşmaktadır ve toplumsal eşitlik olarak adlandırımıştır. Faktörün iç tutarlık katsayısı $\alpha=.866$ olarak hesaplanmıştır. ìkinci faktör ise yedi maddeden oluşmaktadır ve iç tutarlık katsayısı $\alpha=.852$ olarak hesaplanmıştır. Ölçeğin iç tutarlılı̆ını tehdit edebilecek olan maddelerin analizden çıkarılması öngörülmüştür. Ortak varyanslara ilişkin istatistikler (communalities) incelendiğinde faktör yük değeri düşük görülen ve çoklu korelasyonların karesinin 0.20'nin altında olduğu tespit edilen bir madde (8. soru) analizden çıkarılmıştır. Bu katsayılar genel olarak faktörlerin kendi içinde oldukça güvenilir olduğunu ve içsel geçerlilikleri olduğunu göstermektedir. Ayrıca yapılan faktör analizinde, sosyal adalet maddelerinden birinin (16.soru) her iki faktöre de yüklendiği ve yüksek faktör değerinin diğer alt boyutta olduğu görülmüştür. Bu nedenle bu madde de sonraki analizlerde kullanılmamış ve sosyal adalet ölçeğinden çıkarılmıştır. Kalan 14 madde ile tekrar yapılan güvenirlik analizi sonucunda "sosyal adalet ölçeği" iç 
tutarlık katsayısı $\alpha=.887$; "toplumsal eşitlik" boyutu iç tutarlık katsayısı $\alpha=.891$; "adil ilişkiler sistemi" boyutu iç tutarlık katsayısı $\alpha=.884$ olarak bulunmuştur. Bu faktörlerde yer alan değişkenleri tespit etmek için yine varimaks metoduyla döndürme işlemi tekrar yapılmıştır. Döndürme işlemi sonucunda oluşan faktör matrisi incelenerek faktörlerde yer alan değişkenler ve faktör yükleri de belirlenmiştir. Yapılan bu ön değerlendirme çalışması sonrasında ölçeğin asıl araştırma sürecinde kullanılmasına karar verilmiş̧ir. Araştırmada yer alan Sosyal Adalet Ölçeği maddeleri aşağıdaki Tablo 3'de sunulmaktadır.

Tablo 3. Sosyal Adalet Ölçeğinin Maddeleri

Bulunduğum toplumda ${ }^{3} .$.

1. bireyler arasında sosyal bir fark olmayıp, herkes eşit hak ve özgürlüklere sahiptir.

2. eğitim-öğretim ve çalışma süreçlerinde çalışanların da idareciler kadar söz sahibi olması sağlanır.

3. sosyal olarak bireyler tüm yönlerden adaletli bir şekilde kurumun olanaklarından yararlanır.

4. tüm bireylere eşit davranılır, olanaklar ve kaynaklar adil şekilde ulaştıııır.

5. kurumlarda düzeni koruyan ve çalışanların haklarını savunabilen bir sistem mevcuttur.

6. kurumlarda idareden başlayıp o kurumun her alanında hiç kimsenin bir diğerine üstünlüğünün olmaması gözetilir.

7. sosyal, fiziksel veya ekonomik yönden farklı olan bireylerin içinde bulundukları durumda ve olayda eşit olması gözetilir.

8. personelin ve eğitimcilerin düşüncelerine önem veren, dikkate alan bir sistem mevcuttur.

9. kişilere eşit mesafede yaklaşma ve hak verme konusunda hassasiyet gösterilir.

10. insanlar birbirleriyle ilişki ve iletişim bakımından eşittir.

11. bireyler diğer insanların haklarını sınırlayana kadar özgürdür.

12. tüm çalışanların huzurlu, mutlu, refah içinde çalışabilmesi için herkesçe paylaşılan kurallar mevcuttur.

13. çalışan bireyler kurumlarında idareciler nezdinde aynı imkânlara sahiptir.

14.herkes hizmetlerden, fırsatlardan, fiziksel ve sosyal olanaklardan eşit şekilde yararlanır.

Araştırma içerisinde, sosyal adalet ölçüm aracı "1=Kesinlikle katılmıyorum", "2=Çok fazla katılmıyorum", "3=Pek katılmıyorum", "4=Biraz katııyorum", "5=Oldukça katılıyorum", "6=Kesinlikle katılıyorum" şeklinde Likert tipi bir derecelendirme ile yer almıştır. Ölçeğin geçerliğini test etmek üzere diğer sosyal sermaye ve örgütsel güven ölçekleri için yapıldığı gibi doğrulayıcı faktör analizi uygulanmış ve iç tutarılıık katsayıları değerlendirilmiştir.

\footnotetext{
${ }^{3}$ Anket formunda iletilen bir yönerge ile, özellikle eğitim kurumları ve eğitimciler göz önünde bulundurularak yanıtlanması istenmiştir.
} 
Seçil BAL TAŞTAN

\section{Bulgular}

\section{1. Ölçeklerin Güvenilirlik ve Geçerlilik Analizleri}

Hair, Black, Babin ve Anderson (2010, s.721) normalleştirilmiş ki-kare olarak ifade edilen $X^{2} / \mathrm{df}^{\prime}$ nin 2' nin altında olması durumunda modelin iyi bir model olduğunu, 5 'in altında olması durumunda ise modelin kabul edilmesi için yeterli olduğunu; ayrıca RMSEA'nın \%95 güven düzeyinde 0,10 'ın altında olması durumunda modelin kabul edilebileceğini belirtmiştir. Tablo 1'de yer alan ve araştırmada kullanılan modellerin (ölçme araçlarının) uyum iyiliği değerlerinin Hair vd. (2010, s.721) ve Kline’a (2011, s.134) göre kabul edilebilir değerler arasında olduğunu söylemek mümkündür.

"Sosyal sermaye ölçeği" için yapılan değerlendirmede, DFA sonuçlarına göre, elde edilen uyum iyiliği değerlerinin kabul edilebilir düzeyde olduğu görülmüştür $\left(\chi^{2} / d f=2,41, s d=144, R M S E A=0,031\right.$, $\mathrm{GFI}=, 94, \mathrm{CFI}=0,93, \mathrm{IFI}=0,93, \mathrm{AGFI}=, 92)$. Sosyal sermayenin her bir alt boyutu için Cronbach alfa iç tutarlıık katsayıları; yapısal sosyal sermaye için 0,852, bilişsel sosyal sermaye için 0,882, ilişkisel sosyal sermaye için ise 0,904 olarak saptanmıştır. Çalışmada ölçeğin toplam iç tutarlıı̆ı ise 0,879 olarak belirlenmiştir. "Örgütsel güven ölçeği" için yapılan analizde, yordama güçleri anlamlı olmayan maddelere rastlanmamış ve elde edilen uyum iyiliği değerlerinin kabul edilebilir düzeyde olduğu tespit edilmiştir ( $\chi^{2} / d f=2,24, s d=141$, RMSEA=0,065, GFI=,88, CFI=0,96, IFI=0,96, AGFI=,95). Genel örgütsel güven ölçeğinin Cronbach alfa iç tutarlıık katsayısı 0,836 olarak belirlenmiştir. Cronbach alfa iç tutarIılık katsayısı yöneticiye duyulan güven boyutu için 0,874 ve örgütsel güven boyutu için 0,846 olarak saptanmıştır. "Sosyal adalet ölçeği" için yapılan incelemede, yordama güçleri anlamlı olmayan madde gözlenmemiş ve uyum iyiliği değerlerinin kabul edilebilir düzeyde olduğu görülmüştür $\left(\chi^{2} / d f=2,47, \mathrm{sd}=139, \mathrm{RMSEA}=0,079, \mathrm{GFI}=, 93, \mathrm{CFI}=0,97, \mathrm{IFI}=0,97, \mathrm{AGFI}=, 89\right)$. "Genel sosyal adalet algısı" ölçeğinin Cronbach alfa iç tutarlııı katsayısı 0,891 olarak tespit edilmiştir. Cronbach alfa iç tutarlıık katsayısı "toplumsal eşitlik" boyutu için 0,898, "adil ilişkiler sistemi" boyutu için 0,884 olarak saptanmıştır. Araştırmada ölçeklerinin uyum iyiliği değerleri Tablo 4, ortalama ve güvenilirlik değerleri Tablo 5 ile sunulmuştur. 
Eskişehir Osmangazi Üniversitesi Sosyal Bilimler Dergisi

Tablo 4. Ölçeklerin Doğrulayııı Faktör Analizi Sonuçları

\begin{tabular}{|c|c|c|c|c|c|}
\hline \multirow[t]{2}{*}{ Gösterge/Indeks } & \multicolumn{3}{|c|}{ Ölçek/Model } & \multicolumn{2}{|c|}{ Referans Değerler } \\
\hline & $\begin{array}{c}\text { Sosyal } \\
\text { Ser- } \\
\text { maye }\end{array}$ & $\begin{array}{l}\text { Örgüt- } \\
\text { sel Gü- } \\
\text { ven }\end{array}$ & $\begin{array}{l}\text { Sosyal } \\
\text { Adalet }\end{array}$ & $\begin{array}{c}\text { Iyi Uyum Iyiliği } \\
\text { Değeri }\end{array}$ & $\begin{array}{c}\text { Kabul Edilebilir Uyum } \\
\text { Iyiliği Değeri }\end{array}$ \\
\hline $\begin{array}{l}\chi^{2} / \mathrm{df} \text { (Normalleş- } \\
\text { tirilmiş } \chi^{2} \text { ) }\end{array}$ & 2,41 & 2,24 & 2,47 & $0 \leq X 2 / d f \leq 2$ & $2<X 2 / d f \leq 5$ \\
\hline $\begin{array}{l}\text { RMSEA (Root } \\
\text { Mean Square Er- } \\
\text { ror of Approx.) }\end{array}$ & 0,031 & 0,065 & 0,079 & $0 \leq \mathrm{RMSEA} \leq 0,05$ & $0,05<$ RMSEA $\leq 0,08$ \\
\hline $\begin{array}{l}\text { GFI (Goodness } \\
\text { Fit Index) }\end{array}$ & 94 & ,88 & 93 & $0,95 \leq \mathrm{GFI} \leq 1,00$ & $0,90 \leq \mathrm{GFI}<0,95$ \\
\hline $\begin{array}{l}\text { AGFI (Adjusted } \\
\text { Goodness of Fit } \\
\text { Index) }\end{array}$ & ,92 & ,95 & 89 & $0,90 \leq A G F I \leq 1,00$ & $0,85 \leq \mathrm{AGFI}<0,90$ \\
\hline $\begin{array}{l}\text { SRMR (Standar- } \\
\text { dize Root Mean } \\
\text { Square Residual) }\end{array}$ & 064 & ,043 & 061 & $0 \leq S R M R \leq 0,05$ & $0,05<$ SRMR $\leq 0,10$ \\
\hline $\begin{array}{l}\text { CFI (Compara- } \\
\text { tive Fit Index) }\end{array}$ & 93 & 0,96 & 0,97 & $0,97 \leq \mathrm{CF} \leq 1,00$ & $0,95 \leq \mathrm{CF} \mid<0,97$ \\
\hline
\end{tabular}

Tablo 5. Araştırmada Yer Alan Değişkenlerin Ortalamaları ve Güvenilirlik Değerleri

\begin{tabular}{lccc}
\hline \hline & Ortalama (M) & Std. Sapma (SD) & Cronbach Alpha $(\alpha)$ \\
\hline Sosyal sermaye algısı & 4,66 & 1,14 &, 879 \\
Yapısal boyut & 4,44 & 1,09 &, 852 \\
Bilişsel boyut & 4,57 & 1,05 &, 882 \\
Ilişkisel boyut & 4,98 & 1,11 &, 904 \\
Örgütsel güven algısı & 3,78 & 1,49 &, 836 \\
Örgüte güven & 3,42 & 1,31 &, 846 \\
Yöneticilere güven & 4,14 & 1,14 &, 874 \\
Sosyal adalet algısı & 3,24 & 1,19 &, 891 \\
Toplumsal eşitlik & 3,47 & 1,22 &, 898 \\
Adil ilişkiler sistemi & 3,02 & 1,01 &, 884 \\
\hline
\end{tabular}

Tablo 5'de görüldüğü gibi, araştırmada yer alan değişkenlere ilişkin elde edilen ortalama, standart sapma ve güvenilirlik değerleri; "Sosyal sermaye yapısal boyut" için ( $M=4,44, S D=1,09, \alpha=., 852)$; "Sosyal sermaye bilişsel boyut" için ( $M=4,57, S D=1,05, \alpha=, 882)$; "Sosyal sermaye ilişkisel boyut" için 
$(M=4,98, S D=1,11, \alpha=, 904)$; "Örgüte güven boyutu" için $(M=3,42, S D=1,31, \alpha=, 846)$; "Yöneticilere güven boyutu" için $(M=4,14, S D=1,14, \alpha=, 874)$; "Toplumsal eşitlik boyutu" için $(M=3,47, S D=1,22$, $\alpha=, 898)$; "Adil ilişkiler sistemi boyutu" için $(M=3,02, S D=1,01, \alpha=, 884)$; "Sosyal sermaye algısı" için $(M=4,66, S D=1,14, \alpha=, 879)$; "Örgütsel güven algısı" için $(M=3,78, S D=1,49, \alpha=, 836)$; "Sosyal adalet algısı" için $(M=3,24, S D=1,19, \alpha=, 891)$ olarak belirlenmiştir.

\subsection{Araştırma Hipotezlerine Yönelik Bulgular}

Araştırmada her üç ölçme aracı Likert tipi 6'lı derecelendirme ile olumludan olumsuza doğru 6 , $5,4,3,2,1$ değerleri verilerek puanlanmış ve yüksek puan değişkenlere yönelik algı düzeylerinin daha yüksek olduğunu göstermiştir. Araştırma verilerin analizinde SPSS paket programı ve Yapısal Eşitlik Modellemesi tekniği kullanılmıştır. Böylece, bu bölümde araştırma örnekleminde yer alan katılımcılar (öğretmen ve idareci) arasındaki sosyal sermaye algısı düzeyinin, algıladıkları örgütsel güven ve sosyal adalet ile ilişkileri ve örgütsel güven ile sosyal adalet algı düzeylerinin sosyal sermaye düzeyi üzerindeki etkilerine dair bulgulara yer verilmiştir. Bu amaçla öncelikle katılımcıların görüşlerine göre okullarındaki sosyal sermaye değerlendirmeleri ile algıladıkları örgütsel güven ve sosyal adalete ilişkin korelasyonlar verilmiş; ardından örgütsel güven ve sosyal adalet alt boyutlarının sosyal sermaye düzeyini yordama düzeyine ilişkin bulgular değerlendirilmiştir.

Tablo 6'daki sosyal sermaye ile örgütsel güven arasındaki korelasyon katsayıları incelendiğinde, örgütsel güvenin her iki alt boyutları ile sosyal sermaye algısı arasında pozitif ve anlamlı bir ilişki olduğu görülmüştür. Korelasyon katsayıları incelendiğinde en yüksek korelasyonun sosyal adalet algısının adil ilişkiler sistemi boyutu ile sosyal sermaye arasında gerçekleştiği görülmüştür. Bu sonuçlar okullarda sosyal sermayenin "örgüte duyulan güven" ile daha fazla ilişkili olduğunu göstermiştir. Değişkenler arası ilişki değerleri Tablo 6'da özetlenmiştir. Tablo 6 'da görüldüğü gibi, toplam örgütsel güven algısı $(r=0,549 p<0,01)$ ile sosyal sermaye arasında anlamlı ve aynı yönde ilişki; toplam sosyal adalet algısı $(r=0,594 p<0,01)$ ile sosyal sermaye arasında anlamlı ve aynı yönde ilişki tespit edilmiştir. Bağımsız değişkenlerin alt boyutları ile ilgili bulgulara bakıldığında, örgüte duyulan güven $(r=0,552$ $p<0,05)$, yöneticilere duyulan güven $(r=0,547 p<0,05)$, toplumsal eşitlik $(r=0,587 p<0,05)$, ve adil ilişkiler sistemi $(r=0,602 p<0,05)$ ile algılanan sosyal sermaye arasında anlamlı ve pozitif ilişkiler olduğu da görülmüştür.

Bununla birlikte, yapısal eşitlik analizi ile model testi sonuçları değerlendirilmiş ve elde edilen uyum iyiliği değerlerine göre, modelin kabul edilebilir bir model olduğu görülmüştür $(X 2 / d f=3,61$; RMSEA=0,063; GFI=0,92; AGFI=0,82 SRMR=0,044 CFI=0,88). Şekil 2'de araştırma modeline ait standardize edilmiş beta değerleri ve $t$ değerleri yer almaktadır. 
Tablo 6. Değişkenlere Ait Korelasyon Değerleri (Pearson Korelasyon Testi)

\begin{tabular}{|c|c|c|c|c|c|}
\hline Değişkenler & 1 & 2 & 3 & 4 & \\
\hline $\begin{array}{l}\text { 1. Örgüte } \\
\text { duyulan güven }\end{array}$ & 1 & & & & \\
\hline $\begin{array}{l}\text { 2. Yöneticilere } \\
\text { duyulan güven }\end{array}$ &, $448^{*}$ & 1 & & & \\
\hline $\begin{array}{l}\text { 3. Toplumsal } \\
\text { eşitlik }\end{array}$ & ,623* & ,595* & 1 & & \\
\hline $\begin{array}{l}\text { 4. Adil ilişkiler } \\
\text { sistemi }\end{array}$ & ,587* &, $577^{*}$ &, $541 *$ & 1 & \\
\hline $\begin{array}{l}\text { 5. Sosyal } \\
\text { sermaye algısı }\end{array}$ &, $552 *$ &, $547^{*}$ &, $587^{*}$ &, $602 *$ & 1 \\
\hline
\end{tabular}

Şekil 2. Model 1-Bağımsız Değişkenlerin Bağımlı Değişken Üzerindeki Etkileri

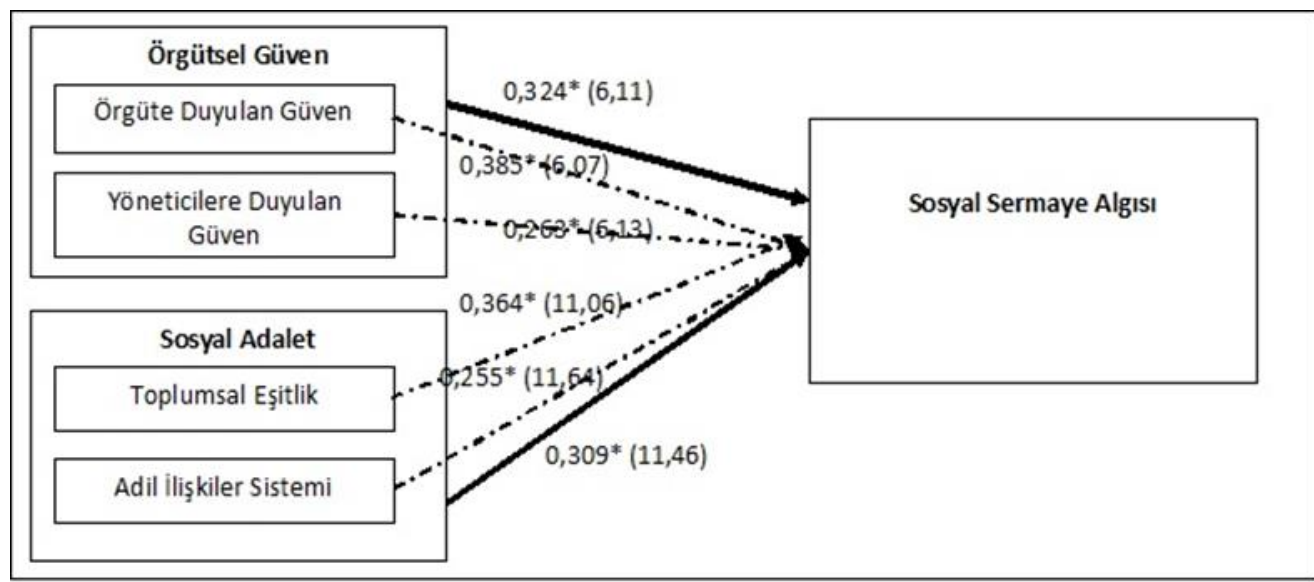

Not: * $p<0,05$ (Parantez içindeki değerler değişkenlerin t değerleridir). Düz çizgiler toplam bağımsız değişkenleri, kesikli çizgiler alt boyutlarını göstermektedir.

Elde edilen bulgulara göre, örgütsel güven algısı "örgüte duyulan güven" boyutunun sosyal sermaye üzerinde (standardize edilmiş $\beta=0,385 ; p<0,05$ ) ve "yöneticilere duyulan güven" boyutunun sosyal sermaye üzerinde (standardize edilmiş $\beta=0,263 ; p<0,05$ ) olumlu bir etkisi bulunmuştur. $B u$ olumlu etkiler, $\mathrm{H} 1$ hipotezini desteklemiştir. Öte yandan, sosyal adalet algısı "toplumsal eşitlik" boyutunun sosyal sermaye üzerinde (standardize edilmiş $\beta=0,364 ; p<0,05$ ) ve "adil ilişkiler sistemi" boyutunun sosyal sermaye üzerinde (standardize edilmiş $\beta=0,255 ; p<0,05$ ) olumlu bir etkisi tespit edilmiştir. Bu sonuçların da $\mathrm{H} 2$ hipotezini desteklediği görülmüştür. ỉkinci modelde örgütsel güvenin alt 
boyutları olan örgüte duyulan güven ve yöneticilere duyulan güven değişkenleri ile sosyal adalet algısının alt boyutları olan toplumsal eşitlik ve adil ilişkiler sistemi değişkenleri bağımsız; sosyal sermaye algısı bağımlı değişken olarak analize dahil edilerek, bağımsız değişkenlerin sosyal sermaye üzerindeki etkilerinin varlığı tek bir model üzerinde test edilmiştir. Şekil 3'de gösterilen modelin test edilmesi sonucunda uyum iyiliği indeksleri (X2/df=4,22; RMSEA=0.044 GFI=0.91; AGFI=0.92 $\mathrm{SRMR}=0.067 \mathrm{CFI}=0.91$ ) kabul edilebilir sınırlar içerisinde bulunmuştur. Modeldeki bağımsız değişkenlerin sosyal sermaye algısı üzerindeki etkileri, \%5 anlamlılık düzeyinde istatistiksel olarak anlamlı çıkmıştır. Tablo 7'de modelde belirtilen yollara ait standardize edilmiş beta ve $p$ değerleri gösterilmiştir. Elde edilen araştırma bulgularına göre, çalışma kapsamında önerilen hipotezler ve bu hipotezlere ilişkin yapısal eşitlik modeli test sonuçları Tablo 8'de sunulmuştur.

Şekil 3. Yapısal Eşitlik Modeli

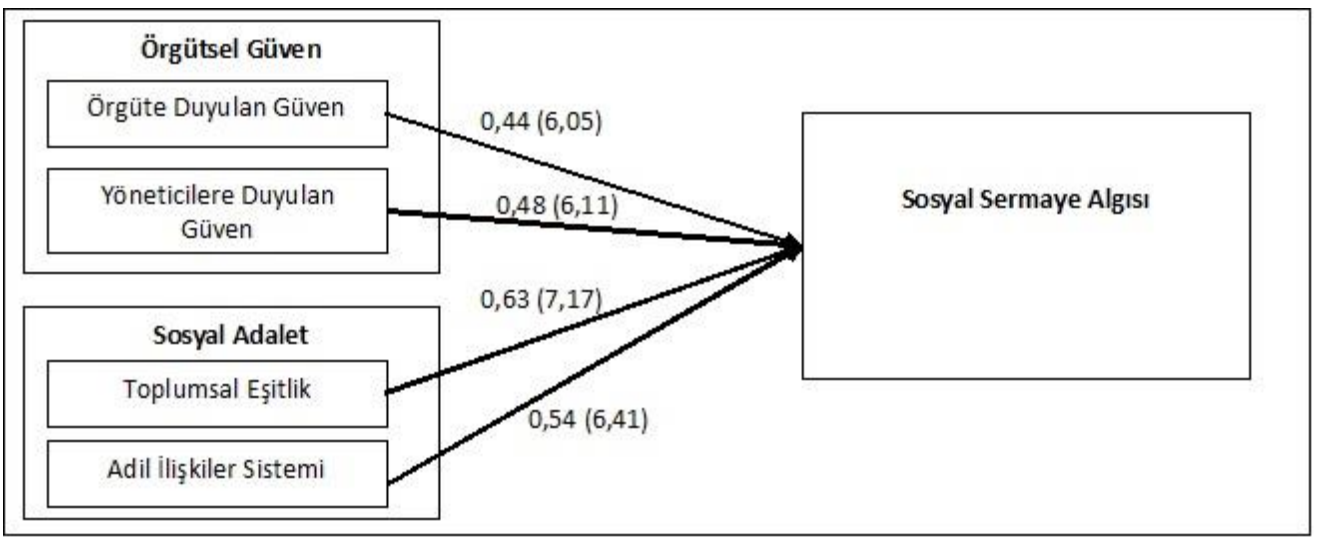

Not: Parantez içindeki değerler değişkenlerin t değerleridir. Düz çizgiler anlamlı ilişkileri göstermektedir.

Tablo 7. Modelin Yol Katsayıları

\begin{tabular}{llll}
\hline \hline Yol & & Standardize 6 & $P^{*}$ \\
\hline Örgüte duyulan güven & $\longrightarrow$ Sosyal sermaye &, 44 &, 01 \\
Yöneticilere duyulan güven & $\longrightarrow$ Sosyal sermaye &, 48 &, 00 \\
Toplumsal eşitlik & $\longrightarrow$ Sosyal sermaye &, 63 &, 03 \\
Adil ilişkiler sistemi & $\longrightarrow$ Sosyal sermaye &, 54 &, 01 \\
\hline
\end{tabular}


Eskişehir Osmangazi Üniversitesi Sosyal Bilimler Dergisi

Tablo 8. Yapısal Eşitlik Modelinin Hipotez Test Sonuçları

Hipotezler

Sonuç

H1: Bireylerin algıladıkları örgütsel güven ile algıladıkları sosyal sermaye yapısı arasında anlamlı bir ilişki vardır.

H1a: Bireylerin çalıştıkları örgüte karşı duydukları güven ile algıladıkları sosyal sermaye yapısı arasında anlamlı bir ilişki vardır.

Kabul

H1b: Bireylerin yöneticilerine karşı duydukları güven ile algıladıkları sosyal sermaye yapısı arasında anlamlı bir ilişki vardır.

Kabul

H2: Bireylerin sosyal adalet algısı düzeyi ile algıladıkları sosyal sermaye yapısı

Kabul arasında anlamlı bir ilişki vardır.*

*Not: Bu çalışmada, sosyal adalet kavramı ile ilgili alt boyutlara yönelik hipotezler oluşturulmamış ancak oluşturulan sosyal adalet algısı ölçüm aracının istatistiksel olarak değerlendirilmesi sonucunda kavramın toplam varyansını açıklayan iki alt bileşen tespit edilmiştir. Böylece elde edilen alt boyutlar hipotez testlerinde analize tabi tutularak her iki alt boyutun da $\mathrm{H} 2$ ana hipotezinde öngörülen doğrultusunda sosyal sermaye ile anlamlı ilişkiler gösterdiği bulgulanmıştır.

\section{Sonuç ve Öneriler}

Araştırmada elde edilen sonuçlara dayalı olarak, bu çalışmanın kapsamında yer alan kavramlara ve kavramlara arasındaki ilişkilere yönelik kuramsal ve uygulamaya dayalı çıkarımlar üzerinde değerlendirmeler yapmak mümkündür. Bu bölümde, çalışmanın sonuçları önceki kavramsal ve kuramsal açıklamalara ve görgül araştırma sonuçlarına da vurgu yaparak tartışılacak ve kuramsal ve uygulama açısından ne gibi çıkarımların olabileceği irdelenecektir.

\subsection{Kurama Yönelik Çıkarımlar}

Örgütsel güvenin, çalışanların davranışlarını (Zalabak, Ellis ve Winograd, 2000), iş performanslarını ve örgütsel bağılııklarını (Paine, 2007; Tanner, 2007; Taşkın ve Dilek, 2010), örgütsel vatandaşlık davranışlarını ve iş tatminlerini (Tüzün, 2006; Yazıcıoğlu, 2009; Gider ve Top, 2010), iş arkadaşları ve yöneticileri olan ilişkilerini (Cummings ve Bromiley, 1996; İslamoğlu, Birsel ve Börü, 2007), örgütsel başarı ve kazanımları (Mishra ve Mishra, 1994), örgütlerde sosyal sermaye düzeyini ve çalışanların sosyal sermaye yapısına ilişkin değerlendirmelerini (Coleman, 1988; Putnam, 1995, 2000; Adler ve Kwon, 2002; Fukuyama, 2005; Özen ve Aslan, 2006; Paşamehmetoğlu, 2010; Başak ve Öztaş, 2010; Gerşil ve Aracı, 2011; Özmen vd., 2014) etkilediği yapılan daha önceki araştırmalarla belirlenmiştir. Bireyler ve birey ile örgüt arasındaki güven, sosyal sermaye kavramının tanımlandığı birçok çalışmada sosyal sermayenin oluşumunda rol oynayan önemli bir unsur olarak vurgulanmıştır (Woolcock ve Narayan, 2009; Fukuyama, 2005; Özen ve Aslan, 2006). Coleman'ın (1988) ve Field'in (2008) da ifade etmiş olduğu gibi, aslında sosyal sermaye gerek toplumlar gerekse örgütler açısından bir kaynağı temsil etmekte ve karşııkılıık ilkesiyle gelişme göstermektedir. Örgüt içerisindeki ilişkilerin yüksek bir güvenle ve ortak değerlerle sürdürülmesi sosyal sermaye rezervlerinin zenginleştirilmesi açı- 
sından önemli bir yere sahip olduğu belirtilmiştir (Field, 2008; Tüysüz, 2011). Böylece, Türkiye'de yapılan çalışmalarda da ifade edildiği gibi, örgüte ve yöneticilere duyulan güvenin yaygın olduğu bir örgüt, bu tür güven unsurlarının zayıf olduğu örgütlere göre daha yüksek sosyal sermaye potansiyeline sahip olabilecektir (Özen ve Aslan, 2006; Paşamehmetoğlu, 2010; Tüysüz, 2011; Duman ve Alacahan, 2011). İstanbul'da hizmette bulunan ilköğretim ve lise düzeyindeki eğitim kurumlarında yapılan bu çalışmada örgütsel güven algılarının bireylerin (öğretmenler ve idarecilerin) sosyal sermaye yapısına ilişkin değerlendirmeleri üzerinde anlamlı etkisinin olduğu belirlenmiştir. Bu etki, daha önce yapılan çalışma sonuçları ile benzerlik göstermektedir ve buna bağlı olarak bireylerin örgütsel güven algılarının ve özellikle bireylerarası ilişkilerde güven düzeyinin artırılması yoluyla örgütün sosyal sermaye düzeyinin olumlu olarak etkilenebileceğini söylemek mümkündür.

Diğer yandan, sosyal sermaye yapısının belirleyici faktörleri arasında yer alan örgütsel adalet ve sosyal adalet gibi kavramların pek çok olumlu örgütsel ve bireysel sonuçları etkilediği yapılan araştırmalarla ortaya konulmuştur (Tomako ve Blacovich, 1994; Karagül ve Masca, 2005; Polat, 2007; Özmen vd., 2007; Helliwel, 2012; Aslan ve Gülaçtı, 2013; Bağcı, 2013). Konu ile ilgili çalışmalarda, sosyal adalet, haklar, bireysel özgürlükler ve eşitlik, ödüllerin dağıtımı, her bireyin yeteneklerinin dikkate alınması gibi unsurlarla açıklanmıştır (Rawls, 1971; Nozick, 2000; Akalın, 1998; Topakkaya, 2009; Sunal, 2011). Aslan ve Gülaçtı (2013) tarafından da ileri sürüldüğü gibi, bireylerin toplumsal yaşamda kendilerini güvende hissetmeleri, bireylerin eşit haklar çerçevesinde ilişkilerde bulunması ve kaynakların adaletli şekilde dağıtılabilmesi için sosyal adalet adı verilen bir takım ideal kurallar ve adil ilişki normlarının bulunması gerekmektedir. Benzer bakış açısı ile, Karagül ve Masca da (2005) bireylerin toplumdaki sosyal adalet sistemine ilişkin olumlu yada olumsuz değerlendirmelerinin, içinde bulundukları örgütsel yapıda sosyal sermayenin arttırılmasında veya azalmasında etkili olabileceğini belirtmişlerdir. Aslında, tüm bu açıklamaların altyapısı mahiyetinde olabilecek tartışmalar Fukuyama (2000), Miller (2001) ve Jost ve Kay (2010) gibi yazarlar tarafından öne sürülmüş olup, özellikle sosyal psikoloji ve yönetim bilimleri açısından sosyal adalet ve örgütsel çıktılar arasındaki ilişkilere vurgu yapılmıştır (Miller, 2001). Bu çalışmalarda, bireysel düzeyde ölçümlenen sosyal adalet algısının yine bireysel düzeyde birtakım algı, tutum ve davranışları olumlu yada olumsuz olarak etkileyerek içinde sosyal sermaye ve insan sermayesinin de bulunduğu pek çok örgütsel sonuç üzerinde etkili olabileceği öne sürülmüştür. Bu noktada, yapılan bu çalışmada da eğitim örgütlerinde bireylerin sosyal adalet algısına sahip olmaları durumunda, sosyal sermaye yapısına ilişkin değerlendirmelerinin de aynı yönde arttığı belirlenmiştir. Böylece, içinde bulunduğu toplumsal düzendeki sosyal adaletin varlığına inanan bireylerin yer aldığı örgütlerde, sosyal sermaye yapısının da daha yüksek düzeyde olabileceğini söylemek mümkündür. Her ne kadar, sosyal adalet ve sosyal sermaye arasındaki bağlantıyı tespit etmiş olan görgül bulgulara yeterince rastlanılmamış olunsa da, sosyal sermaye kavramı literatürü, kendilerini güvenli ve adaletli bir sistemin parçası olarak gören bireylerin, birbirleriyle daha olumlu sosyal ilişkiler kurduğu, politik davranışların azalma eğilimi gösterdiği ve örgütün sosyal yapısının çok daha güçlendiği öne sürülmüştür (Miller, 2001; Harvey, 2001; Fukuyama, 2001; Altay, 2007). Böylece, bu çalışmada elde edilen sonuçların önceki çalışmalarla ve kavramların arkasındaki literatür ile uyumlu olduğu söylenebilmektedir. 
Öte yandan, bu çalışmanın ana kavramlarından biri olan sosyal adalet algısı, Türkiye'de ve uluslararası literatürde kuramsal, felsefi, sosyolojik ve ekonomik bakış açıları ile üzerinde fazlaca durulan bir kavram olmasına karşın, kavramın yönetim, organizasyon ve davranış bilimleri kapsamına giren konularla bir arada yeterince ele alınmadığı görülmüştür. Bu bakımdan, bu çalışmanın söz konusu kavramın daha iyi irdelenebilmesi ve yönetim ve örgütsel davranış kapsamında örgütsel sonuçlar ile olan etkileşiminin anlaşılabilmesi açısından önemli katkıları olacağı düşünülmektedir. Bununla birlikte, çalışmamızın metod bölümünde de belirtildiği gibi, sosyal adaletin işe vuruk tanımını ve ölçüm aracını sağlamış olan çalışmalara yeterince rastlanamamıştır. Bu çalışmada ise, yapılan araştırma sonucunda, elde edilen sosyal adalet boyutlarının güvenilirlik ve geçerlilik değerlerinin kabul edilebilir olduğu görülmüş ve özellikle Miller (1999) tarafından öne sürülmüş olan sosyal adalet boyutları ile uyum gösterdiği gözlenmiştir. Daha önce de belirtildiği gibi, Miller (1999) sosyal adaletin dört unsurunu hak etme, gereksinimler, yasal haklar ve eşitlik olarak kavramsallaştırmıştı. Miller'e (1999, 2001) göre sosyal adaleti bu dört unsurun dengede olduğu bir durum olarak tanımlamak mümkündü. Bu noktada, araştırmamızda elde edilen toplumsal eşitlik ve adil ilişkiler sistemi bileşenlerinin sosyal adalet algısını açıkladığının görülmesi ve bu bileşenlerin Miller (2001) tarafından yapılan sosyal psikoloji ve bireyler arası ilişkiler çalışmalarında öne sürülmüş olan bileşenlerle uyumlu olması söz konusudur. Diğer yandan, Türkiye'de yönetim ve örgütsel davranış literatüründe, örgütlerde çalışmakta olan bireyler üzerinde sosyal adalet algısının ölçümlenmesini sağlayan genel kabul görmüş bir ölçüm aracının bulunmasının oldukça güç olmasından dolayı bu çalışmada kullanıımış olan ölçeğin sonraki benzer akademik çalışmalara katkı sağlayabileceği söylenebilmektedir.

\subsection{Uygulamaya Yönelik Çıkarımlar}

İstanbul'da bulunan ilk-orta ve lise düzeyindeki eğitim kurumlarında görev yapmakta olan öğretmenler ve idareciler örnekleminde yapılan bu çalışmada örgütsel güven ve sosyal adalet algısının eğitimcilerin kurumları ile ilgili olarak sosyal sermaye yapısına ilişkin değerlendirmelerini olumlu yönde etkilemekte olduğu belirlenmiştir. Bu etkiye bağlı olarak eğitim kurumlarındaki yöneticilerin ve eğitim örgütlenmesindeki idari mensupların okullardaki sosyal sermaye yapısını ve bu yapıda yer alan eğitimcilerin sosyal sermaye yaratma potansiyelini artırma konusunda örgütsel güven yaratma uygulamalarına, sosyal adalet unsurlarından olan eşitlik ve adil ilişkiler konularına ve sosyal sermayeyi oluşturan tüm yapısal ve ilişkisel faktörlere önem vermelerinin yararlı olacağını söylemek mümkündür. Özellikle okul idarecilerinin ve Türkiye'de eğitim örgütlenmesinde yer alan tüm kurum ve karar mekanizmalarının adil bir sosyal yapı, eşit haklar ve muamele, temel haklar ve bireylerarası adil paylaşım gibi konuları daha iyi düzenlemesi ve kurumlardaki güven ilişkilerinin arttırılması, birey-kurum ve birey-idareciler ilişkilerinin daha olumlu bir güven temeline dayandırıması için çaba göstermesi eğitimcilerin ve eğitim kurumlarının da sosyal sermaye potansiyelinin artmasına katkıda bulunabilecektir. Ayrıca eğitim kurumlarındaki idarecilerin, terfilerde, ödüllendirme ve cezalandırmalarda, bireylerarası ilişkilerde adil ve tutarlı davranışlar göstererek, eğitimcilerin kuruma ve idarecilere güvenlerini artırabileceği söylenebilmektedir. 
Seçil BAL TAŞTAN

\section{3. Çalışmanın Sınırıııkları ve Yapılacak Çalışmalar İçin Öneriler}

Bu çalışma ilk, orta ve lise düzeyindeki eğitim kurumlarında görev yapmakta olan eğitimcilerin örgütsel güven, sosyal adalet ve sosyal sermaye algıları konusunda literatüre ve uygulamaya dönük katkılar barındırmasına rağmen, belirli kısıtlara da sahiptir. Öncelikle, bu araştırma, yalnızca İstanbul ilindeki eğitim kurumlarında gerçekleştirilmiş ve veri toplama süreci yaklaşık 8 ay devam etmesine rağmen (Mart.2014-Ekim.2014), evreni temsil edecek yeterli örneklem büyüklüğüne ulaşılamamıştır. Ayrıca tercih edilen kolayda örnekleme yöntemi çalışmanın diğer kısıtını oluşturmaktadır. Bununla birlikte, çalışma kesitsel desenli ve ilişkisel bir çalışmadır. Bu nedenle değişkenler arasında bulunan istatistiksel ilişkiler neden sonuç bağlamında değerlendirilememektedir. Bu da çalışmanın bir kısıtı olarak görülmektedir. Çalışmanın veri toplama tekniği ve örneklemin büyüklüğü göz önüne alındığında, araştırma modelinde yer alan değişkenler arasında nedensellik ilişkisinin de tespit edilebilmesi mümkün olamamaktadır. Bundan sonraki çalışmalarda, kota örneklemesinin kullanılması ve farklı illeri de kapsayacak daha geniş araştırma alanlarında gerçekleştirilmesi tavsiye edilmektedir. Bir diğer kısıt ise bu çalışmanın İstanbul ili örneklemindeki Milli Eğitim Bakanlığı'na bağlı devlet okullarındaki öğretmen ve idarecileri kapsamında yapılmış olmasıdır. Konum, büyüklük, eğitim yönetimi, yönetim şekli itibariyle özel okulların da araştırma kapsamına alınmasıyla farklı özelliklere sahip eğitim kurumları örnekleminde yapılacak olan çalışmalarda değişik sonuçlar elde edilmesi de olası bir durum olarak karşımıza çıkmaktadır. Bu nedenle, bu çalışma kapsamında önerilen kavramlar arası ilişkilerin, farklı nitelikteki eğitim kurumlarında ve farklı sektörlerde (Üniversiteler, Sağılı Kurumları, Belediyeler, Turizm ve Otel İşletmeleri, Sanayi Kuruluşları, Çokuluslu Şirketler, vb.) yer alan kamu ve/veya özel kuruluşlarda araştırıması ile hem literatüre hem de uygulamaya katkı sağlayacağı düşünülmektedir. Diğer yandan, bu çalışmada tüm değişkenler çalışanların kişisel beyanı ile oluşan tek bir kaynaktan ölçülmüş olup, ortak yöntem varyansının sonuçlar üzerindeki etkisi istatistiksel olarak kontrol edilememektedir. Ortak yöntem varyansının etkisi kontrol edilememiş olduğundan, bu durum araştırmanın bir diğer kısıtını oluşturmaktadır (Bkz. Podsakoff, Mackenzie, Lee ve Podsakoff, 2003 , s.881). Bununla birlikte, araştırma kavramlarının kültürel psikoloji ve toplumsal kültür ile yakın ilişkili olması düşüncesiyle, bu kavramların kültürler arası bir karşılaştırmaya imkan verebilecek yöntemlerle araştııılması tavsiye edilmektedir. Öyle ki, örgütsel güven ve sosyal adalet gibi kavramların kültürden kültüre farklılaşabileceği ve sosyal sermaye yapısının kültürel zeminden etkilenebileceği varsayımıyla, sonraki çalışmalarda uygulanabilecek kültürler arası bir araştırmanın çok daha fazla katkı sağlayabileceği düşünülmektedir.

\section{Kaynaklar}

Abdioğlu, H. ve S. Yavuz (2013). "İşletmelerde Sosyal Sermayenin Ölçümlenmesi Ve Raporlanmasına Yönelik Bir Araştırma", Journal of Economics \& Administrative Sciences/Afyon Kocatepe Üniversitesi İktisadi ve İdari Bilimler Fakültesi Dergisi, 15(1), 43-18.

Adler, P. S. ve S.W. Kwon, (2002). "Social Capital: Prospects for a New Concept", Academy of Management Review, 27(1), 17-40. 
Akalın, G. (1998). "İnsan Hakları, Fırsat Eşitliği ve Türkiye", Türkiye’de İnsan Hakları III Sempozyumu, Türk Demokrasi Vakfı, Ankara, Türkiye.

Akbari, P., M. Sharafi, ve T. Vatandost (2012). "A study of the relationship between perceived organizational justice and social capital of staff (case study: physical education general department of Ilam province)", International Journal of Sport Studies, 2(9), 455-464.

Akçay, S. (2005). "Sosyal Sermaye ve Kalkınma”, Ed. M. Kar, S. Taban, iktisadi Kalkınmada Sosyal, Kültürel ve Siyasal Faktörlerin Rolü, Ekin Kitabevi, Bursa.

Aksoy, M. (2009). İşletmelerde Örgütsel Güven Anlayışının Algılanması ve Demografik Değişkenler Açısından Analizi, Yayınlanmamış Yüksek Lisans Tezi, Gazi Üniversitesi Sosyal Bilimler Enstitüsü, Ankara.

Alp, S. ve A. Karakaş (2008). Asimetrik Bilgi Teorisi Karşısında Hayek'in Ekonomik Yaklaşımları: Karşılaştırmalı Bir Analiz, Ankara: Ankara Kitabevi.

Asunakutlu, T. (2006). "Çalışanlar ile yöneticiler arasında güven duygusunun araştırılması: Turizm sektöründe bir uygulama", Dokuz Eylül Üniversitesi Sosyal Bilimler Enstitüsü Dergisi, 8(4), 16-33.

Aslan, S. ve F. Gülaçtı (2013). "Üniversite Öğrencilerinin Sosyal Adalete Illişkin Görüşleri", Erzincan Üniversitesi Eğitim Fakültesi Dergisi, 15(1), 203-214.

Aydemir, M. A. (2011). Sosyal Sermaye: Topluluk Duygusu ve Sosyal Sermaye Araştırması. Konya: Çizgi Kitabevi Yayınları.

Aydemir, M. A. ve M.C. Özşahin (2011). "Türk Demokrasisinde Kayıp Halkayı Keşfetmek: Türkiye Örneği Üzerinden Sosyal Sermaye-Demokrasi Bağlantısını Yeniden Düşünmek", Akademik incelemeler Dergisi, 6(1), 1-27.

Aydemir, M. A. ve E. Tecim (2012). "Türk Toplumunda Aile ve Dinin Sosyal Sermaye Potansiyeli", Selçuk Üniversitesi Sosyal Bilimler Enstitüsü Dergisi, 28, 43-59.

Ayios, A., R. Jeurissen, ve L.J. Spence (2010). "Social Capital: A Review from an Ethics Perspective. http://bura.brunel.ac.uk/handle/2438/4432, Erişim: 21.05.2014.

Bağcı, Z. (2013). "Çalışanların Örgütsel Adalet Algılarının Örgütsel Bağılııları Üzerindeki Etkisi: Tekstil Sektöründe Bir İnceleme", Uluslararası Yönetim iktisat ve Işletme Dergisi, 9(19), 163-184.

Başak, S. ve N. Öztaş (2010). "Güven Ağbağları, Sosyal Sermaye ve Toplumsal Cinsiyet", iktisadi ve idari Bilimler Fakültesi Dergisi, 12(1), 1-30.

Bayram, N. (2010). Yapısal Eşitlik Modellemesine Giriş: AMOS Uygulamaları. İstanbul:Ezgi Kitabevi.

Beaulieua, L. J., G. D. Israel, G. Hartless, ve P. Dyk (2001). "For Whom Does the School Bell Toll?: Multi-Contextual Presence of Social Capital and Student Educational Achievement", The Journal of Socio-Economics, 30(2), 121-127. 
Seçil BAL TAŞTAN

Behn, R. D. (1995). "The Big Questions of Public Management", Public Administration Review, 313324.

Bourdieu, P, (1986). "The Forms of Capital", J. Richardson (Ed.) Handbook of Theory and Research for the Sociology of Education, New York: Greenwood Press, 241-258.

Bryk, A. ve B. Schneider (2002). Trust in Schools: A Core Resource for Improvement. New Jersey: Russell Sage Foundation.

Buluç, B. (2007). "Eğitimin Amaç ve İşlevleri", Karip Emin (Ed.), Eğitim Bilimine Giriş içinde, PegemA Yayıncilık, Ankara.

Burt, R.S, (2000). "Structural Holes versus Network Closure as Social Capital", Lin, N., Cook, C.S., Burt, R.S. (Ed.) Social Capital: Theory and Research. New York, Aidine de Gruyter.

Büte, M. (2011). "Kayırmacılığın Çalışanlar Üzerine Etkileri İle İnsan Kaynakları Uygulamaları ilişkisi: Türk Kamu Bankalarına Yönelik Bir Araştırma", Atatürk Üniversitesi Sosyal Bilimler Enstitüsü Dergisi, 15(1), 172-184.

Büyüköztürk, Ş., E.K. Çakmak, Ö.E. Akgün, Ş. Karadeniz, ve F. Demirel (2008). Bilimsel Araştırma Yöntemleri. Ankara: Pegema Yayıncılık.

Chang, H. H. ve Chuang, S. S. (2011). "Social capital and individual motivations on knowledge sharing: Participant involvement as a moderator", Information \& management, 48(1), 9-18.

Chiu, C. M., Hsu, M. H. ve Wang, E. T. (2006). "Understanding knowledge sharing in virtual communities: An integration of social capital and social cognitive theories", Decision Support Systems, 42(3), 1872-1888.

Cohen, D. ve L. Prusak (2001). In Good Company: How Social Capital Makes Organizations Work, U.S.A.:Harvard Business Press.

Cohen, L., L. Manion, ve K. Morrison (2007). Research Methods in Education. London: Routledge Falmer.

Coleman, J. S. (1988). "Social Capital in the Creation of Human Capital", American Journal of Sociology, 94, 95-120.

Coleman, J. S. (1990). Foundations of Social Theory, Cambridge: Harvard University Press.

Coleman, J. S. (1998). "Social Capital in the Creation of Human Capital", American Journal of Sociology, University of Chicago, 95-120.

Colquitt, J. A. (2001). "On the dimensionality of organizational justice: a construct validation of a measure", Journal of Applied Psychology, 86(3), 386-405.

Colquitt, J. A., J. Greenberg, ve C.P. Zapata-Phelan (2005). "What is organizational justice? A historical overview", Handbook of organizational justice, 1, 3-58. 
Condeluci, A., M. G., Ledbetter, D. Ortman, J. Fromknecht, ve M. DeFries (2008). "Social Capital: A View from the Field", Journal of Vocational Rehabilitation, 29(3), 133-139.

Cote, S. (2001). "The contribution of human and social capital", Canadian Journal of Policy Research, 2(1), 29-36.

Cubela, A. V. ve T. Kvartuc (2007). "Effects of Mobbing on Justice Beliefs and Adjustment", European Psychologist, 12(4), 261-271.

Cummings, L. L. ve P. Bromiley (1996). "The Organizational Trust Inventory (OTI)", Trust in Organizations: Frontiers of Theory and Research, 302, 330.

Çelikten, M., M. Şanal, ve Y. Yeni (2005). "Öğretmenlik Mesleği ve Özellikleri", Erciyes Üniversitesi Sosyal Bilimler Enstitüsü Dergisi, 19(2), 207-237.

Çetin, M. (2006). "Endüstriyel Bölgelerde Sosyal Sermaye ve Güven: Üçüncü İtalya Örneği", Ege Academic Review, 6(1), 74-86.

DeConinck, J. B. (2010). "The Effect of Organizational Justice, Perceived Organizational Support, and Perceived Supervisor Support on Marketing Employees' Level of Trust", Journal of Business Research, 63(12), 1349-1355.

Defilippis, J. (2001). "The Myth of Social Capital in Community Development", Housing Policy Debate, 12(4), 781-806.

Demircan, N. (2003). "Örgütsel Güvenin Bir Ara Değişken Olarak Örgütsel Bağlılık Üzerindeki Etkisi: Eğitim Sektöründe Bir Uygulama", Yayımlanmamış Doktora Tezi, Kocaeli: Gebze İleri Teknoloji Enstitüsü, Sosyal Bilimler Enstitüsü.

Demircan, N. ve A. Ceylan (2003). "Örgütsel güven kavramı: Nedenleri ve sonuçları", Yönetim ve Ekonomi: Celal Bayar Üniversitesi Iktisadi ve Idari Bilimler Fakültesi Dergisi, 10(2), 139-150.

Deutsch, M. (1999). "A Personal Perspective on the Development of Social Psychology in the Twentieth Century", Reflections On, 100, 1-34.

Dinga, E. (2014). "Social capital and social justice", Procedia Economics and Finance, 8, 246-253.

Dolan, P. (2008)."Social support, social justice, and social capital: A tentative theoretical triad for community development", Community Development, 39(1), 112-119.

Durdağ, M. ve A. Naktiyok (2011). "Psikolojik Taciz Algısının Örgütsel Güven Üzerindeki Rolü", Kafkas Üniversitesi iiBF Dergisi, 1-2.

Duman, B. ve O. Alacahan (2011). "Etniklik ve Sosyal Kaynaşma ilişkisi: Adana Örneği", Cumhuriyet Üniversitesi iktisadi ve Idari Bilimler Dergisi, 12(1), 223-244. 
Seçil BAL TAŞTAN

Eckerd, A., H.E. Campbell, ve Y. Kim (2013). "Social Capital and Environmental Justice: An AgentBased Model", Methods For Addressing Social System Complexity In Policy Evaluation, 7(3), 430.

Eğriboyun, D. (2013). "Ortaöğretim Okullarında Görev Yapan Yönetici ve Öğretmenlerin Örgütsel Güven, Örgütsel Destek ve Örgütsel Bağlııkları Arasındaki Ilişki (Bolu Ili Örneği)", Yayınlanmamış Doktora Tezi, Bolu: Abant İzzet Baysal Üniversitesi, Eğitim Bilimleri Enstitüsü.

Eisenberger, R., R. Huntington, S. Hutchison, ve D. Sowa (1986). "Perceived organizational support", Journal of Applied Psychology, 71, 500-507.

Ekinci, A, (2008). "Genel Liselerdeki Sosyal Sermaye Düzeyinin ÖSS Başarısına Etkisi", Yayımlanmamış Doktora Tezi, Elazığ: Fırat Üniversitesi Sosyal Bilimler Enstitüsü.

Ekinci, A. (2012). "Illköğretim Okullarındaki Sosyal Sermaye Düzeyinin Örgüt İçi Paylaşıma Etkisi, Kuramdan Uygulamaya Eğitim Bilimleri Dergisi, 12(4), 2505-2520.

Ekinci, A. ve M. Karakuş (2011). "Okul Müdürlerinin Sosyal Sermaye Liderliği Davranışlarının Öğretmenler Arasındaki Sosyal Sermaye Düzeyine Etkisi", Kuram ve Uygulamada Eğitim Yönetimi Dergisi, 17(4), 527-553.

Elster, J. (1992). Local Justice: How Institutions Allocate Scarce Goods and Necessary Burdens, Russell Sage Foundation.

Erdem, F. ve J. Özen (2003). Cognitive and Affective Dimensions of Trust in Developing Team Performance, Team Performance Management, 9(5/6), 131-135.

Etcheverry, E. (1996). "Social Capital: A Resource for The Human Capital Development of University Students", Yayınlanmamış Doktora Tezi, Manitoba: University of Manitoba, Faculty of Education.

Feinberg, J. (1973). Social Philosophy, New Jersey: Prentice-Hall.

Field, J. (2008). Sosyal Sermaye, (Çev.B. Bilgen, B. Şen), İstanbul: İstanbul Bilgi Üniversitesi Yayınları.

Francois, P. (2003). Social Capital and Economic Development, Routledge.

Frankena, W. K. (1962). "The Concept of Social Justice", Social Justice, 1, 17.

Fukuyama, F. (2000). Büyük Çözülme, İnsanın Doğası Ve Toplumsal Düzenin Yeniden Oluşumu, (Çev. Z. Avcı, A.T.Aydemir), İstanbul: Sabah Kitapları.

Fukuyama, F. (2005). Güven, Sosyal Erdemler ve Refahın Yaratılması (Çev. A.Buğdaycı), İstanbul, İ̧̧ Bankası Kültür Yayınları.

Fukuyama, F. (1995). Trust: Social Virtues and The Creation of Prosperity. London: Hamish Hamilton. 
Gerşil, G. S. ve M. Aracı (2011). "Sosyal Sermayenin Güven Unsurunun İşgörenlerin Performansı Üzerine Etkileri", Çalışma ve Toplum, 1, 39-79.

Gewirtz, S. (2006). "Towards a Contextualized Analysis of Social Justice in Education", Educational Philosophy and Theory, 38 (1), 69-81.

Giddens, A. (2004). Modernliğin Sonuçları, İstanbul: Ayrıntı Yayınları.

Gil, D. G. (2006). "Reflections on Health and Social Justice", Contemporary Justice Review, 9(1), 3946.

Göksel, A., B. Aydıntan, ve D. Bingöl (2010). "Örgütlerde Bilgi Paylaşım Davranışı: Sosyal Sermaye Boyutundan Bir Bakış", Ankara Üniversitesi SBF Dergisi, 65(4), 087-109.

Granovetter, M. (1985). "Economic Action and Social Structure: The Problem of Embeddedness", American Journal of Sociology, 91 (3), 1-22.

Greenberg, J. (1987). "A taxonomy of organizational justice theories", Academy of Management Review, 12(1), 9-22.

Greenberg, J. (1990). "Organizational justice: Yesterday, today, and tomorrow", Journal of Management, 16(2), 399-432.

Hair, J. F., W.C. Black, B.J. Babin, ve R.E. Anderson (2010). Multivariate Data Analysis, 7. Basım, Saddle River, NJ: Prentice Hall, Inc.

Harvey, D. (2001). "Sınıf ilişkileri, Sosyal Adalet ve Farklılık Politikası", Praksis, 2, 173-203.

Hau, Y. S., B. Kim, H. Lee, ve Y. G. Kim (2013). "The Effects of Individual Motivations and Social Capital on Employees' Tacit and Explicit Knowledge Sharing Intentions", International Journal of Information Management, 33(2), 356-366.

Helliwel, J. F. (2012). “Contribution of Human and Social Capital to Sustained Economic Growth and Well-being", Symposium Report, Department of Economics, University of British Colombia.

Hooper, D., J. Coughlan, ve M. Mullen (2008). "Structural Equation Modelling: Guidelines for Determining Model Fit", Electronic Journal of Business Research Methods, 6(1), 53-60.

http://www.oecd.org/innovation/research/1825902.pdf

İslamoğlu, G., D. Börü, ve M. Birsel (2007). Kurum İçinde Güven: Yöneticiye, İ̧̧ Arkadaşlarına ve Kuruma Yönelik Güven Ölçümü (Alan Araştırması ve Sonuçları), İstanbul: İnkılap Kitabevi.

İşcan, Ö. F. ve U. Sayın (2011). "Örgütsel Adalet, İş Tatmini ve Örgütsel Güven Arasındaki Ilişki", iktisadi ve Idari Bilimler Dergisi, 24(4), 200-222

Jost, J. T. ve A.C. Kay (2010). Social Justice: History, Theory, and Research, Handbook of Social Psychology, IW Publishing. 
Seçil BAL TAŞTAN

Kalaycioğlu, E. (2007). "Politics of Conservatism in Turkey", Turkish Studies, 8(2), 233-252.

Kalkışım, M. M. (2013). "Kutadgu Bilig'de Adâlet Değeri", Mavi Atlas GŞÜ Edebiyat Fakültesi Dergisi, Güz, 91-98.

Karagül, M. ve M. Masca (2005). "Sosyal Sermaye Üzerine bir İnceleme", AïÜ-ïBß Ekonomik ve Sosyal Araştırmalar Dergisi, 1, 37-52.

Karaeminoğulları, A. (2006). "Öğretim elemanlarının örgütsel adalet algıları ile sergiledikleri üretkenliğe aykırı davranışlar arasındaki ilişki ve bir araştırma", Yayınlanmamış Yüksek Lisans Tezi, İstanbul Üniversitesi Sosyal Bilimler Enstitüsü, İstanbul.

Karasar, N. (2013). Bilimsel Araştırma Yöntemleri, Ankara: Nobel Yayın Dağııım.

Keskin, M. (2008). "Sosyal Sermaye ve Bölgesel Kalkınma: Erzurum Ticaret ve Sanayi Odası Üyelerinde Sosyal Sermaye Düzeyi ve Belirleyicilerinin Analizi", Yayınlanmamış Doktora Tezi, Erzurum: Atatürk Üniversitesi Sosyal Bilimler Enstitüsü Iktisat Ana Bilim Dalı.

Kline, R.B. (2011). Principles and Practice of Structural Equation Modeling, 3. Basım, New York: The Guilford Press.

Korczynski, M. (2000). "The Political Economy of Trust", Journal of Management Studies, 37(1), 118.

Korczynski, M. (2003). "Communities of Coping: Collective Emotional Labour in Service", Work Organization, 10(1), 55-79.

Krackhardt, D. (1992). "The Strength of Strong Ties: The Importance of Philos in Organizations", Networks and Organizations: Structure, Formand Action, 216-237.

Lee, V. E. ve R. C. Croninger (2001)."The Elements of Social Capital in the Context of Six High Schools", The Journal of Socio-Economics, 30(2), 165-167.

Leon-Guerrero, A. (2010). Social Problems: Community, Policy, and Social Action, U.S.A: Pine Forge Press.

Lin, N. (1999), "Building A Network Theory of Social Capital", Connections, 22(1), 28-51.

Luhmann, N. (1998). Observations on Modernity, US.A.: Stanford University Press.

McPodolny, J. ve J. Baron (1997). "Resources and Relationships: Social Networks and Mobility in the Workplace", American Sociological Review, 62(1), 673--693.

Mill, J. S. (2000). Özgürlük Üstüne (Çev.: Alime Ertan), İstanbul: Belge Yayınları.

Miller, D. (1999). Principles of Social Justice, U.S.A.:Harvard University Press.

Miller, D. T. (2001). "Disrespect and the Experience of Injustice", Annual Review of Psychology, 52(1), 527-553. 
Mishra, A. K. ve K.E. Mishra (1994). The Role of Mutual Trust in Effective Downsizing Strategies, Human Resource Management, 33(2), 261-279.

Montada L. (1998). Justice: Just a Rational Choice?", Social Justice Research, 11, 81-101.

Moorman, R. H. (1991). "Relationship between organizational justice and organizational citizenship behaviors: Do fairness perceptions influence employee citizenship?", Journal of Applied Psychology, 76(6), 845-865.

Moran, P. ve S. Ghoshal (1996). "Value Creation By Firms", Academy of Management Proceedings, 1, 41-45.

Nahapiet, J. ve S. Ghoshal (1998). "Social Capital, Intellectual Capital, and the Organizational Advantage", Academy of Management Review, 23(2), 242-266.

Narayan, D. ve M. F. Cassidy (2001). "A Dimensional Approach to Measuring Social Capital: Development and Validation of a Social Capital Inventory", Current Sociology, 49(2), 59-102.

Norris, P. (2002). "Social capital and the news media", The Harvard International Journal of Press/Politics, 7(1), 3-8.

Nozick, R. (2000). Anarşi, Devlet ve Ütopya, (Çev.: A.Oktay), İstanbul: İstanbul Bilgi Üniversitesi Yayınları.

Nyhan, R. C. ve H.A. Marlowe (1997). "Development and Psychometric Properties of the Organizational Trust Inventory", Evaluation Review, 21(5), 614-635.

Oba, B. ve F. Semerciöz (2005). "Antecedents of Trust in Industrial Districts: An Empirical Analysis of Inter-Firm Relations in a Turkish Industrial District", Entrepreneurship \& Regional Development, 17(3), 163-182.

Onyx, J. ve P. Bullen (2000), "Measuring social capital in five communities", The Journal of Applied Behavioral Science, 36(1), 23-42.

Öğüt, A. ve C. Erbil (2009). Sosyal sermaye yönetimi, Ankara:Çizgi Kitabevi.

Ören, K. (2007). "Sosyal Sermayede Güven Unsuru ve İşgücü Performansına Etkisi", Kamu-Iş, 9(1), 71-90.

Özdemir, A. A. (2006). "Çalışanların İş Tatminlerinin Artırılmasında Örgütsel Sosyal Sermaye Yeni Bir Belirleyici Olabilir Mi?", Anadolu Üniversitesi Yönetim Bilimleri Dergisi, 6(1), 22-36.

Özdemir, A. A. (2008). "Sosyal Ağ Özellikleri Bakış Açısıyla Sosyal Sermaye ve Bilgi Yaratma ilişkisi: Akademisyenler Üzerinde Yapılan Bir Alan Araştırması", Anadolu Üniversitesi Sosyal Bilimler Dergisi, 8(2), 1-21. 
Seçil BAL TAŞTAN

Özen, Ş., ve Z. Aslan (2006). "İçsel ve Dışsal Sosyal Sermaye Yaklaşımları Açısından Türk Toplumunun Sosyal Sermaye Potansiyeli: Ortadoğu Sanayi ve Ticaret Merkezi (OSTiM) Örneği", Akdeniz IiBF Dergisi, 12, 130-161.

Özmen, F., C. Aküzüm, E. Koçoğlu, Ç. Tan, ve M. Demirkol (2014). "Eğitim Kurumlarında Sosyal Sermayenin İ̧ Tatmini Üzerindeki Etkisi", Ekev Akademi Dergisi, 18(58), 333-346.

Özmen, Ö. N., Y. Arbak, ve P. S. Özer (2007). "Adalete Verilen Değerin Adalet Algıları Üzerindeki Etkisinin Sorgulanmasına İlişkin Bir Araştırma", Ege Akademik Bakış Dergisi, 7(1), 17-33.

Öztaş, N. (2007). "Sosyal Sermayenin Ağbağ Kuram(lar)ı: Dayanışmacı ve Aracı Sosyal Sermaye", Amme Idaresi Dergisi, 40(3), 79-98.

Paine, S. C. (2007). "The Relationship Among Interpersonal and Organizational Trust and Organizational Commitment", Yayınlanmamış Doktora Tezi, San Diego: Alliant International University, Marshall Goldsmith School of Management.

Pastoriza, D. (2008). "Antecedents and Consequences of the Internal Social Capital of Organizations: An Empirical Study", IESE Business School, clsbe.lisboa.ucp.pt., 1-41, Erişim: 18.02.2014.

Paşamehmetoğulları, A. (2010). "Kültürel Değerlerde Farklılaşmanın Sosyal Sermayeye Etkileri: Ankara Mobilyacılar Sitesi (Siteler) ve Ortadoğu Sanayi ve Ticaret Merkezi (Ostim) Üzerine Bir Araştırma", Yayınlanmamış Doktora Tezi, Ankara: Başkent Üniversitesi, Sosyal Bilimler Üniversitesi, İşletme Anabilim Dalı.

Podsakoff, P. M., S.B. Mackenzie, J.L. Lee, ve N.P. Podsakoff (2003). "Common Method Biases in Behavioral Research: A Critical View of the Literature and Recommended Remedies", Journal of Applied Psychology, 88, 879-903.

Polat, S. (2007). "Eğitim Politikalarının Sosyal Adalet Açısından Sonuçları Konusunda Yönetici ve Öğretmen Görüşleri”, Yayımlanmamış Doktora Tezi, Ankara: Ankara Üniversitesi Eğitim Bilimleri Enstitüsü.

Polat, S. (2009). Eğitim örgütleri için sosyal sermaye: örgütsel güven. Ankara: PegemA Yayıncılık.

Ployhart, R. E. ve A.M. Ryan (1997). "Toward an explanation of applicant reactions: An examination of organizational justice and attribution frameworks", Organizational Behavior and Human Decision Processes, 72(3), 308-335.

Pussa, A., ve U. Tolvanen (2006). "Organizational Identity and Trust", Electronic Journal of Business Ethics and Organization Studies, 11(2), 29-33.

Putnam, R. (2004). Education, Diversity, Social Cohension and Social Capital. Paper Presented at the Meeting of OECD Education Ministers Report, 18-19 March, Dublin, http://www.oecd.org/ dataoecd/37/55/30671102. doc, Erişim: 11.01.2014. 
Putnam, R. D. (2000). Bowling Alone: The Collapse and Revival of American Community, New York, Simon and Schuster.

Putnam, R.D. (1995). "Bowling Alone: America's Declining Social Capital", Journal of Democracy, 6 (1), 65-78.

Rawls, J. (1971). A Theory of Justice, Cambridge: Belknap Press of Harvard University Press.

Ribbers, I.L. (2009). Trust, cnynicism, and organizational change: The role of management, Yayınlanmmaış Yüksek Lisans Tezi, University of Tilburg Department Organisation and Strategy, Tilburg, Netherlands.

Sağlam, F. (2008). "Hukuk Devletinin Vazgeçilmez Ögesi Sosyal Devlet”, Eksiksiz Demokrasi Sempozyumu Kitabı, Ankara: TBB Yayını.

Sağlam, R. (2007). "Liberal Adaletin İki Farklı Görünümü: John Rawls ve Robert Nozick "Hakkaniyet Olarak Adalet" Eleştirisinden "Yetkisel Adalet" Eleştirisine", Erzincan Üniversitesi Hukuk Felsefe Dergisi, 11 (1-2), 181-217.

Sargut, S. (2006). "Sosyal sermaye: Yapının sunduğu bir olanak mı, yoksa bireyin amaçlı eylemi mi?", Akdeniz IïBF Dergisi, 1, 1-13.

Sargut, S. (2001). Kültürlerarası Farklılaşma ve Yönetim, Ankara: İmge Yayınevi.

Sargut, S. (2003). "Kurumsal Alanlardaki Örgüt Yapılarının Oluşmasında ve Ekonomik İşlemlerin Yürütülmesinde Güvenin Rolü", F. Erdem (Der.), Sosyal Bilimlerde Güven, Ankara: Vadi Yayınları, 89-124.

Schuller, T. (2001). "The Complementary Roles of Human and Social Capital", Canadian Journal of Policy Research, 2(1), 18-24.

Shockley-Zalabak, P., K. Ellis, ve G. Winograd (2000). "Organizational trust: What it means, why it matters", Organization Development Journal, 18(4), 35-55.

Stanton-Salazar, R. ve S. Dornbusch (1995). Socail Capital and the Reproduction of Inequality: Information Networks Among Mexican-Origin High School Students", Sociology of Education, 68 (2), 116-135.

Sunal, O. (2011). "Sosyal Politika:Sosyal Adalet Açısından Kuramsal Bir Değerlendirme", Ankara Üniversitesi SBF Dergisi, 66(3), 283-305.

Şahin, A. E. (2008). "A Qualitative Assessment of the Quality of Turkish Elementary Schools", Eurasian Journal of Educational Research, Winter (30), 117-139.

Şan, M. K. (2007). "Sosyal Bilimlerde Yıldızı Yükselen Yeni Bir Kavram: Sosyal Sermaye ve Türkiye”, Sosyoloji Yazıları I: Sakarya Üniversitesi Sosyoloji Bölümü Ortak Çalışması, M.K. Şan (Ed.). İstanbul: Kızıl Elma Yayınları. 
Şimşek, R.D. (2013). "ilkokul ve Ortaokullardaki Sosyal Sermaye Düzeyi ile Öğretmenlerin İş Doyumları Arasındaki İlişkinin İncelenmesi", Yayınlanmamış Yüksek Lisans Tezi, İstanbul: Okan Üniversitesi Sosyal Bilimler Enstitüsü, İşletme Bölümü.

Tan, H. H. ve C. S. Tan (2000). "Toward the differentiation of trust in supervisor and trust in organization", Genetic, Social, and General Psychology Monographs, 126(2), 241-260.

Tanner, B. M. (2007). An Analysis of the Relationships Among Job Satisfaction, Organizational Trust, and Organizational Commitment in an Acute Care Hospital, Yayınlanmamış Doktora Tezi, New Jersey: Saybrook Graduate School And Research Center.

Taşkın, F., ve R. Dilek (2010). "Örgütsel Güven ve Örgütsel Bağlılık Üzerine Bir Alan Araştırması", Organizasyon ve Yönetim Bilimleri Dergisi, 2(1), 37-46.

Taştan, M., ve K. Yılmaz (2008). "Örgütsel Vatandaşlık ve Örgütsel Adalet Ölçeklerinin Türkçeye Uyarlanması", Eğitim ve Bilim, 33(130), 87-96.

Tecim, E. (2011). Sosyal Güven: Sosyal Sermaye ve Dindarlık Çatışması, Konya: Çizgi Kitabevi.

Temple, J. (2000). "Growth Effects of Education and Social Capital in the OECD", International Symposium on the Contribution of Human and Social Capital to Sustained Economic Growth and Well-being, Québec City, Canada, 19-21.

Tomako J, ve J. Blascovich (1994). "Effects of Justice Belifes on Cognitive Appraisals of and Subjective, Physiological, and Behavioral Response to Potential Stress, Journal of Personal Psychology, 67, 732-740.

Top, M., Ö. Gider, ve D. Ünalan (2010). "Hastane Sektöründe İş Performansını Etkileyen Örgütsel Değişkenlerin (Faktörlerin) İncelenmesi: Kayseri ve Kocaeli illerindeki Hemşireler Üzerine Bir Alan Araştırması", İ̧letme iktisadı Enstitüsü Yönetim Dergisi, 66, 71-96.

Topaloğlu, I. G. (2010). İşgörenlerin adalet ve etik algıları açısından örgütsel güven ile örgütsel bağ|lık ilişkisi. Yayımlanmamış Yüksek Lisans Tezi, Atılım Üniversitesi, Sosyal Bilimler Enstitüsü, İstanbul.

Topakkaya, A. (2006). "Bir Söylem Olarak Sosyal Adalet Kavramı", Erciyes Üniversitesi Hukuk Fakültesi Dergisi, 1(2), 97-111.

Topakkaya, A. (2009). "Aristoteles"te Adalet Kavramı", Uluslararası Sosyal Araştırmalar Dergisi, 2(6), 628-634.

Topçuoğlu, A. (2003). Akrabalık ve Hemşerilik Illişkilerinin Toplumsal Sermaye Değeri. Konya: Çizgi Kitabevi.

Toprak, A. G. E., H. Bozgeyikli (2011). "Öğretmen Adaylarının Sosyal Sermaye Düzeylerinin Karşılaştırmalı İncelenmesi", Erciyes Üniversitesi Sosyal Bilimler Enstitüsü Dergisi, 3, 125-147. 
Töremen, F. (2002). "Okullarda Sosyal Sermaye: Kavramsal Bir Çözümleme", Kuram ve Uygulamada Eğitim Yönetimi Dergisi, 32, 568-585.

Tsai, W., ve S. Ghoshal (1998). "Social Capital and Value Creation: The Role of Intrafirm Networks", Academy of Management Journal, 41(4), 464-476.

Tschannen-Moran, M. (2004). "What's Trust Go To Do With It? The Role of Faculty and Principal Trust in Fostering Student Achievement", University Council for Educational Administration Annual Convention, Kansas City, http://mxtsch.people. wm.edu/vitae.php, Erişim: 11.01.2014.

Tuncay, T. ve E. Erbay (2006). "Sosyal Hizmetin Temel Hedefi: Sosyal Adalet - Güçlendirme ile Retorikten Pratiğe", Toplum ve Sosyal Hizmet, 17(1):53-69

Turgut, E. ve M. Beğenirbaş (2013). "Çalışanların Yenilikçi Davranışları Üzerinde Sosyalsermaye ve Yenilikçi iklimin Rolü: Sağlık Sektöründe Bir Araştırma", KHO Bilim Dergisi, 23(2), 101-124.

Tüylüoğlu, Ş. (2006). "Sosyal sermaye, iktisadi performans ve kalkınma: Bir yazın taraması", Akdeniz ii BF Dergisi, 12, 14-60.

Tüysüz, N. (2011). "Sosyal Sermayenin Ekonomik Gelişme Açısı Önemi ve Sosyal Sermaye Endeksinin Hesaplanması", Uzmanlık Tezi, Kalkınma Bakanlı̆̆ı, Yayın No: 2827,

Tüzün, İ. K. (2006). "Örgütsel Güven, Örgütsel Kimlik ve Örgütsel Özdeşleşme Illişkisi; Uygulamalı Bir Çalışma". Yayınlanmamış Doktora Tezi, Ankara: Gazi Üniversitesi Sosyal Bilimler Enstitüsü.

Uslaner, E. M. (1999). "Democracy and Social Capital", Democracy and Trust, 121-150.

Van Wormer, K. S. (2004). Confronting Oppression, Restoring Justice: From Policy Analysis To Social Action, U.S.A.:Council on Social Work Education.

Yücel, C. ve Kalaycı, S. G.(2009). "Örgütsel güven ve örgütsel vatandaşlık davranışı", Fırat Üniversitesi Sosyal Bilimler Dergisi, 19(1), 113-132.

Wallen, N. E. ve J. R. Fraenkel (2001). Educational Research: A Guide to the Process. Psychology Press.

Walzer, M. (1983). Spheres of Justice: A Defense of Pluralism and Equality, U.S.A.: Basic Books.

Wasko, M. M. ve Faraj, S. (2005). "Why should I share? Examining social capital and knowledge contribution in electronic networks of practice", MIS Quarterly, 35-57.

Woolcock, M. ve D. Narayan (2000). "Social Capital: Implications for Development Theory, Research, and Policy", The World Bank Research Observer, 15(2), 225-249.

Yazıcıoğlu, İ. (2009). "Konaklama İşletmelerinde İşgörenlerin Örgütsel Güven Duyguları Ille İş Tatmini ve İşten Ayrılma Niyetleri Üzerine Bir Alan Araştırması”, Elektronik Sosyal Bilimler Dergisi, 8(10), 235-249. 


\section{Seçil BAL TAŞTAN}

Zalabak, S. P., K. Ellis, ve G. Winograd (2000). "Organizational Trust: What it Means, Why It Matters", Organization Development Journal, 12(4), 21-40. 